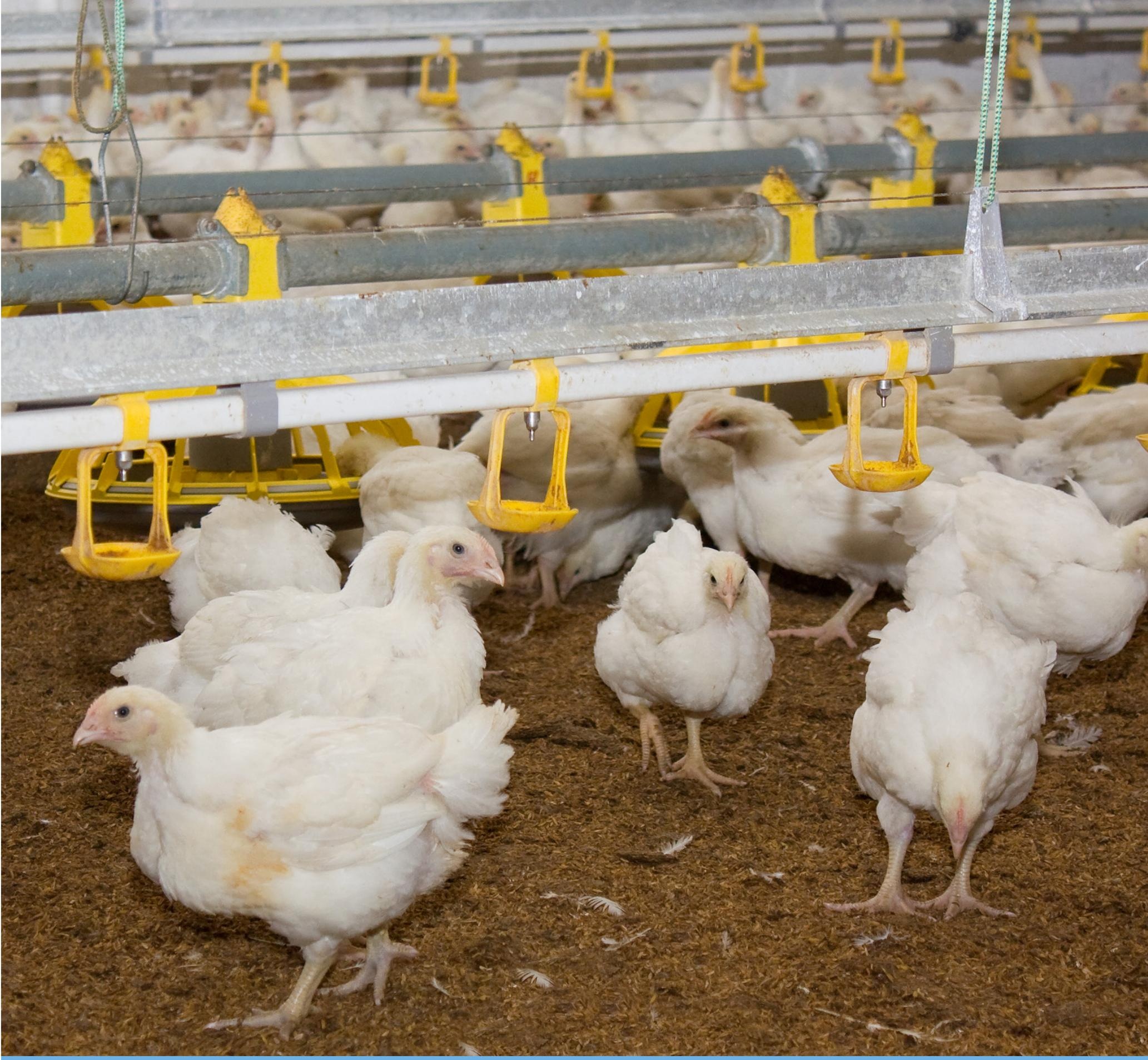

Retrospectieve analyse van standaard

vastgelegde data in de vleeskuikenproductieketen

I.C. de Jong, J.W. van Riel 



\section{Retrospectieve analyse van standaard vastgelegde data in de vleeskuikenproductieketen}

I.C. de Jong, J.W. van Riel

Dit onderzoek is uitgevoerd door Wageningen UR Livestock Research en gefinancierd door het publiek-private samenwerkingsproject 'Gezonde Vleeskuikenketen' (TKI-AF-14216) BO-23.05-001-013

Wageningen UR Livestock Research

Wageningen, februari 2017 
De Jong, I.C., Van Riel, J., 2017. Retrospectieve analyse van standaard vastgelegde data in de vleeskuikenproductieketen. Wageningen UR (University \& Research centre) Livestock Research, Livestock Research Rapport 1013.

Samenvatting Dit rapport beschrijft de analyse van data die worden vastgelegd binnen de verschillende schakels van een deel van de Nederlandse de vleeskuikenproductieketen, met als doel om bronnen van grote variatie in prestatie- en gezondheidskenmerken van vleeskuikenkoppels op te sporen. Data werden vastgelegd in de periode 2011-2014 en betroffen op koppelniveau geaggregeerde gegevens van productiekenmerken, verzameld op niveau van het vermeerderingsbedrijf, de broederij, het vleeskuikenbedrijf en de slachterij. Na correctie voor effecten van seizoen, tijdstrend en leeftijd van de moederdieren bleken in deze dataset constante verschillen tussen vermeerderingskoppels wat betreft prestatie en gezondheid van de vleeskuikens gering, en constante verschillen tussen vermeerderingsbedrijven nagenoeg afwezig. Uit de analyse bleek dat het vleeskuikenbedrijf zelf en de gebeurtenissen tussen het leggen van het ei en het plaatsen van het kuiken op het vleeskuikenbedrijf een relatief grote rol spelen in de variatie in uitval, groei, afkeur, uniformiteit en antibioticagebruik op het vleeskuikenbedrijf. Belangrijk daarbij is dat deze analyse het effect van incidenten (zoals het doormaken van een infectie) op het vermeerderings- en opfokbedrijf niet kon inschatten omdat deze gegevens niet op detail niveau worden vastgelegd. Nader onderzoek wordt uitgevoerd om te bepalen in welke mate incidenten in de voorschakels, zoals het doormaken van een infectie, de technische resultaten en gezondheid van vleeskuikens beïnvloeden.

Summary In the current report routinely collected data of a part of the Dutch broiler production chain are analysed, with the aim to find major sources of variation contributing to indicators of production and health performance in broiler chickens. Data were collected between 2011 and 2014 and involved aggregated data on flock level of production figures, which were collected at the level of parent stock production period, hatchery, broiler farm and slaughter plant. The statistical model adjusted for effects of season, year trend and parent stock age. In the current dataset, constant differences with respect to broiler performance and health were relatively small between broiler breeder flocks and nearly absent between breeder production farms. The analysis showed that the broiler farm and factors or events between laying of the egg at the production farm and placement of day-old chicks at the broiler farm had the largest effect on the variation in mortality, growth performance, rejections and antibiotic treatments of broiler chickens. It is important to consider that in the current analysis the effect of single events in the parent stock (e.g., a disease in the breeder flock) could not be taken into account, because the effects of these events have not been registered in detail. Further research will be carried out to determine to what extent 'events' in the breeder flock affect the production and health performance of broiler flocks.

Dit rapport is gratis te downloaden op http://dx.doi.org/10.18174/408607 of op www.wur.nl/livestock-research (onder Wageningen Livestock Research publicaties).

(C) 2017 Wageningen UR Livestock Research, Postbus 338, 6700 AH Wageningen, T 03174839 53, E info.livestockresearch@wur.nl, www.wageningenUR.nl/livestockresearch. Livestock Research is onderdeel van Wageningen UR (University \& Research centre).

Livestock Research aanvaardt geen aansprakelijkheid voor eventuele schade voortvloeiend uit het gebruik van de resultaten van dit onderzoek of de toepassing van de adviezen.

Alle rechten voorbehouden. Niets uit deze uitgave mag worden vermenigvuldigd en/of openbaar gemaakt worden door middel van druk, fotokopie, microfilm of op welke wijze dan ook zonder voorafgaande toestemming van de uitgever of auteur.

De certificering volgens ISO 9001 door DNV onderstreept ons kwaliteitsniveau. Op als onze onderzoeksopdrachten zijn de Algemene Voorwaarden van de Animal Sciences Group van toepassing. Deze zijn gedeponeerd bij de Arrondissementsrechtbank Zwolle. 


\section{Inhoud}

$\begin{array}{lr}\text { Woord vooraf } & \mathbf{5}\end{array}$

$\begin{array}{ll}\text { Samenvatting } & 7\end{array}$

$\begin{array}{ll}1 & \text { Inleiding }\end{array}$

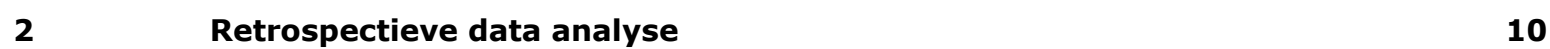

$\begin{array}{lll}2.1 & \text { Doelstelling } & 10\end{array}$

2.2 Methoden 10

2.2.1. Databronnen en beschikbare data 10

$\begin{array}{ll}2.2 .2 \text {. Aantal records } & 10\end{array}$

2.2.3. Materiaal en redenatie bij ordening van data richting fase van analyse 11

2.2.4. Analyse 1 , schatting van gemiddelde effecten van seizoen, leeftijd moederdieren en tijdstrend, en daarnaast (simultaan) het schatten van variatiebronnen

2.2.5. Analyse 2 , relatie vleeskuikenkenmerken met productiekenmerken vermeerderingskoppels

9 10 (0 0 10

2.2.6. Analyse 3, relatie vleeskuikenbedrijfseffecten en afstand broederijvleeskuikenbedrijf 14

2.3 Resultaten 14

2.3.1. Variantiecomponenten 17

2.3.2. Resultaten analyse 2: relatie vleeskuikenkenmerken met productiekenmerken vermeerderingskoppels

2.3.3. Resultaten analyse 3: relatie afstand broederij-vleeskuikenbedrijf met vleeskuikenbedrijfseffect

3 Beknopte literatuurstudie

3.1 Analyse ketendata en mogelijke verbanden $\quad 22$

$\begin{array}{lll}3.2 & \text { Transgenerationele effecten } & 23\end{array}$

$\begin{array}{lll}3.3 & \text { Conclusies } & 24\end{array}$

4

$\begin{array}{ll}\text { Discussie en conclusies } & 26\end{array}$

$\begin{array}{lll}4.1 & \text { Conclusies en aanbevelingen } & 28\end{array}$

$\begin{array}{lr}\text { Literatuur } & 29\end{array}$

$\begin{array}{lll}\text { Bijlage } 1 \text { Verklaring termen } & 30\end{array}$

Bijlage 2 Effecten van trend, seizoen en leeftijd moederdieren 31

Bijlage 3 Schattingen voor variantiecomponenten 32 



\section{Woord vooraf}

Het onderzoek beschreven in dit rapport is uitgevoerd in het kader van het project 'Gezonde Vleeskuikenketen' (TKI-AF-14216). De PPS Gezonde Vleeskuikenketen is een publiek-private samenwerking tussen de overheid (ministerie van Economische Zaken) en het pluimveebedrijfsleven. Binnen de PPS werkt de kennisinstelling Wageningen Livestock Research samen met PLUIMNED, 2SistersStorteboom, Aviagen EPI, Kuikenbroederij Munsterhuis, Broederij Elshuis, De Hoop Mengvoeders en De Heus Voeders.

Wij danken de partners in het project voor het aanleveren en controleren van de databestanden die gebruikt zijn in het hier beschreven onderzoek.

Ingrid de Jong (projectleider) 


\section{Samenvatting}

Over het algemeen wordt aangenomen dat er een invloed is van de omstandigheden waaronder vleeskuikenouderdieren worden gehouden èn gebeurtenissen tijdens de opfok- en vermeerderingsfase op de technische prestatie, de gezondheid en het welzijn van de vleeskuikens. Dit staat ook beschreven in de wetenschappelijke literatuur, maar de vraag is of we deze effecten ook aan kunnen tonen met data uit de praktijk. Bovendien, welke factoren in de praktijk van invloed zijn en welke niet, in welke mate deze effecten aanwezig zijn, en hoe deze factoren in het leven van de ouderdieren een effect hebben op de nakomelingen (de onderliggende mechanismen), daarover is nog maar zeer weinig bekend.

In de vleeskuikenproductieketen worden op routinematige basis een aantal kenmerken binnen de verschillende schakels vastgelegd. Deze kenmerken worden meestal weergegeven als koppelgemiddelde of het gemiddelde over een periode van weken; voorbeelden zijn het antibioticagebruik van een koppel, de uitval of de eiproductie. Een analyse van deze routinematig geregistreerde gegevens kan inzicht geven in mogelijke verbanden tussen gebeurtenissen/factoren in de voorschakels (opfok, vermeerdering en broederij) en prestatie (technisch, gezondheid en dierenwelzijn) van het vleeskuikenkoppel.

In dit rapport wordt een eerste verkenning gemaakt of het mogelijk is om met praktijkgegevens de effecten van gebeurtenissen in de voorschakels te relateren aan de technische resultaten en de gezondheid van de vleeskuikens. Deze informatie kan mogelijk in een later stadium gebruikt worden om de pluimveevleesketen te optimaliseren en het antibioticagebruik verder te verminderen.

Routinematig verzamelde gegevens van een deel van de Nederlandse vleeskuikenproductieketen die zijn vastgelegd in de periode 2011-2014 zijn aan elkaar gekoppeld. Gegevens vastgelegd op het niveau van het vleeskuikenbedrijf en de slachterij, en op het niveau van het vermeerderingsbedrijf zijn vervolgens geanalyseerd. Van de daaraan voorafgaande opfokfase waren te weinig gegevens bekend voor een betrouwbare analyse. Van 1267 vleeskuikenkoppels waren herkomst- en productiegegevens bekend; deze waren afkomstig van 154 vermeerderingskoppels en 70 vermeerderingsbedrijven. Per vermeerderingskoppel waren gemiddeld 10 geregistreerde vleeskuikenkoppels in de database (overige vleeskuikenkoppels waren geen onderdeel van de geanalyseerde keten).

We hebben geanalyseerd in welke mate de variatie in groei, afkeur aan de slachtlijn, uitval eerste week, uitval totaal en dierdagdosering (antibiotica gebruik) van een vleeskuikenkoppel werden verklaard door (a) het vermeerderingsbedrijf en (b) vermeerderingskoppel waarvan de vleeskuikens afkomstig waren, (c) de gebeurtenissen tussen het leggen van het ei en het afleveren van het kuiken aan het vleeskuikenbedrijf (hier 'kuikenleverantie' genoemd; dit betreft o.a. bewaarduur van de eieren, transportfactoren en broederijomstandigheden), (d) het vleeskuikenbedrijf zelf, (e) de stal op het vleeskuikenbedrijf $(f)$ een vaste combinatie vermeerderingsbedrijf - vleeskuikenbedrijf en ( $g$ ) stal binnen een kuikenleverantie.

Voor ieder gemeten vleeskuikenkenmerk (groei, uitval totaal en eerste week, afkeur aan de slachtlijn en antibioticagebruik) werden de gemiddelde effecten geschat van seizoen, leeftijd moederdieren en tijdstrend (tussen 2011 en 2014) en tegelijkertijd werd de invloed van de verschillende schakels (benoemd in a tot en met $\mathrm{g}$ hierboven) geschat.

Seizoensinvloeden werden gevonden voor de kenmerken uitval (totaal en eerste week) en afkeur; in de zomerperiode werd een lagere afkeur en uitval gezien dan in de winterperiode. Een significante tijdstrend werd gevonden voor antibioticumgebruik (dalend tussen 2011 en 2014), groei, eindgewicht en uitval totaal (stijgend tussen 2011 en 2014) en uniformiteit (eerst dalend, daarna weer stijgend). Groei en eindgewicht werden beïnvloed door de leeftijd van de moederdieren; bij jonge moederdieren werd een lagere groei en eindgewicht gevonden dan bij oudere moederdieren. 
Na het schatten van de seizoensinvloed, invloed van leeftijd moederdieren en tijdstrend werd voor ieder kenmerk op vleeskuikenniveau geschat wat de bijdrage was van de verschillende (onderdelen van) schakels in de keten aan de resterende variantie van deze kenmerken. Uit deze analyse bleek dat, na correctie voor seizoen, tijdstrend en leeftijd moederdieren, constante verschillen tussen vermeerderingsbedrijven en vermeerderingskoppels wat betreft de gemeten vleeskuikenkenmerken in deze dataset afwezig of zeer klein waren. Dat betekent dat er met de gebruikte dataset er geen effecten konden waargenomen van het vermeerderingsbedrijf op de prestatie en gezondheid van de vleeskuikens. Wanneer specifiek naar de invloed van vermeerderingskoppel werd gekeken werden de grootste constante verschillen tussen vermeerderingskoppels gevonden voor de kenmerken 'afkeur' en 'uniformiteit' bij vleeskuikens.

De bijdrage van het vleeskuikenbedrijf zelf, de gebeurtenissen tussen het leggen van het ei en het afleveren van het kuiken op het bedrijf (hier 'kuikenleverantie' genoemd), en de specifieke stal binnen deze leverantie, aan de variatie in kenmerken op het vleeskuikenbedrijf was relatief groot. Dus de omstandigheden rondom het broedei en het vleeskuiken waren van groter belang dan het vermeerderingsbedrijf of - koppel. Het vleeskuikenbedrijf zelf had een relatief groot effect op de kenmerken groei en eindgewicht en totale uitval, terwijl de meeste variatie in eerste weeks uitval en antibioticagebruik werden verklaard door de gebeurtenissen tussen het leggen van het ei en het plaatsen van het kuiken op het vleeskuikenbedrijf ('kuikenleverantie').

Gemiddeld gezien heeft het vermeerderingskoppel en -bedrijf dus een relatief klein effect op de prestatie van het vleeskuikenkoppel en lijkt het grootste effect te worden veroorzaakt door factoren/gebeurtenissen na het leggen van het ei bij het moederdier. Uit de literatuur is ook bekend dat bijvoorbeeld bewaarduur van eieren, broedomstandigheden en opvangcondities op het vleeskuikenbedrijf van belang zijn voor de prestatie van het vleeskuikenkoppel, naast uiteraard het management op het vleeskuikenbedrijf. Belangrijk is wel om daarbij niet uit het oog te verliezen dat we hier over grote bronnen van variatie spreken en dat de invloed van incidenten (zoals het doormaken van een infectie of een incident met het klimaat) op het vermeerderingsbedrijf niet onderzocht kon worden omdat gegevens daarover niet routinematig worden vastgelegd in databases.

Een aanvullende analyse van de relatie tussen productiekenmerken op het vermeerderingsbedrijf en de prestatie van vleeskuikenkoppels liet zien dat er een positieve correlatie was tussen aantal eieren, piekproductie en uitkomstpercentage van het ouderdierkoppel en de uniformiteit van het vleeskuikenkoppel bepaald aan de slachtlijn, wat betekent dat een hogere productie samengaat met een slechtere uniformiteit. Verder onderzoek is nodig naar de oorzaak van dit verband.

In vervolgonderzoek zal de analyse nogmaals worden herhaald over een grotere tijdsperiode, om te onderzoeken of de gevonden effecten robuust zijn. Daarnaast zal verder onderzoek uitgevoerd worden naar de mate waarin gebeurtenissen in de voorschakels (zoals het doormaken van een infectie) de prestatie van het vleeskuikenkoppel beïnvloeden. Dit betreft een meer gedetailleerde registratie van gegevens op verschillende niveaus in de keten. De nadruk zal daarbij liggen op de prestatie van het vleeskuikenkoppel in de eerste week, omdat op basis van deze studie daar de meeste invloed van de voorschakels wordt verwacht, en na de eerste levensweek het effect van het management op het vleeskuikenbedrijf relatief groot zal zijn. 


\section{$1 \quad$ Inleiding}

Over het algemeen wordt aangenomen dat er een invloed is van de omstandigheden waaronder vleeskuikenouderdieren worden gehouden èn gebeurtenissen tijdens de opfok- en vermeerderingsfase op de technische prestatie, de gezondheid en het welzijn van de vleeskuikens. Uit gesprekken met erfbetreders, vermeerderaars, opfokkers en andere personen binnen de vleeskuikensector blijkt dat iedereen wel een idee heeft over mogelijke effecten van factoren of gebeurtenissen in de voorschakels op het laatste deel van de vleeskuikenketen, de vleeskuikens zelf. Ook zijn er aanwijzingen uit de literatuur dat deze effecten bestaan. Echter, welke factoren van invloed zijn en welke niet, in welke mate deze effecten aanwezig zijn, en hoe deze factoren in het leven van de ouderdieren een effect hebben op de nakomelingen (de onderliggende mechanismen), daarover is echter nog maar zeer weinig bekend.

In het project 'Gezonde Vleeskuikenketen' worden stappen gezet om de relatie tussen de omstandigheden en prestatie van vleeskuikenouderdieren, en de gezondheid en prestatie van de vleeskuikens verder te ontrafelen. Gezocht wordt naar mogelijke factoren/gebeurtenissen in het leven van de vleeskuikenouderdieren die voorspellend kunnen zijn voor de prestatie, de gezondheid en het welzijn van de vleeskuikens. Hierbij zou mogelijk gebruik gemaakt kunnen worden van bestaande databases.

In de vleeskuikenproductieketen worden op routinematige basis al een aantal kenmerken binnen de verschillende schakels vastgelegd. Voorbeelden hiervan zijn productiekenmerken (zoals aantal eieren en bevruchtingspercentage) en antibioticagebruik van vermeerderingskoppels, uitkomst- en overlegpercentages binnen de broederijschakel en antibioticagebruik, afkeurgegevens, uitval en technische prestatie van het vleeskuikenkoppel. Een analyse van deze standaard geregistreerde gegevens kan inzicht geven in mogelijke verbanden tussen gebeurtenissen/factoren in de voorschakels (opfok, vermeerdering en broederij) en prestatie (technisch, gezondheid en dierenwelzijn) van het vleeskuikenkoppel.

Dit rapport beschrijft de resultaten van een analyse van data die routinematig in het verleden zijn geregistreerd door de ketenpartners binnen dit project of in nationale databases; dit betreft dus een deel van de Nederlandse vleeskuikenproductieketen. In de database waren opgenomen gegevens van vleeskuikenkoppels en koppels ouderdieren in de opfok- en vermeerderingsfase die in de periode vanaf 2011 tot eind 2014 vastgelegd zijn. Deze analyse kan gezien worden als een eerste stap in de zoektocht naar mogelijke verbanden tussen factoren/gebeurtenissen binnen de verschillende schakels van de vleeskuikenketen. Daarnaast is er een zeer beknopte literatuurstudie uitgevoerd naar mogelijke verbanden tussen gebeurtenissen of factoren in de voorschakels en op het vleeskuikenbedrijf. De resultaten van deze beknopte literatuurstudie worden eveneens in deze rapportage weergegeven. 


\section{Retrospectieve data analyse}

\section{$2.1 \quad$ Doelstelling}

Doelstelling van de retrospectieve data analyse was om grote bronnen van variatie in gezondheids- en productiekenmerken van de vleeskuikenfase op te sporen, en daarmee dus de vraag te beantwoorden of het mogelijk is om met gegevens uit bestaande databases effecten op te sporen van gebeurtenissen of factoren in de voorschakels op de gezondheid of de prestatie van vleeskuikenkoppels.

Dit hoofdstuk beschrijft de analyse van ketendata verzameld bij de partners die deelnemen aan de PPS gezonde vleeskuikenketen en betreft dus een deel van de Nederlandse vleeskuikenketen. Er is gekozen voor de selectie van data vanaf het moment dat het antibioticagebruik werd geregistreerd in de databank CRA (centrale registratie van antibiotica, www.avined.nl) en het analyseren van gegevens van vermeerderingskoppels die volledig waren afgesloten. Dat betekent dat de analyse is uitgevoerd met gegevens uit de periode van 2011 tot en met eind 2014.

Een verklaring van de gebruikte termen in dit hoofdstuk is te vinden in Bijlage 1.

\subsection{Methoden}

\subsubsection{Databronnen en beschikbare data}

Bij deze analyse werd gebruik gemaakt van verschillende databases uit de vleeskuikenproductieketen, waarin op standaard wijze door partijen data werden vastgelegd. Deze databases zijn vervolgens aan elkaar gekoppeld. De databases waren:

(1) Database van de slachterij, met hierin opgenomen gegevens over daggroei, groei index (groei gecorrigeerd voor leeftijd), geslacht gewicht, afkeurpercentage, percentage uniformiteit (het percentage kuikens < 65\% van het gemiddelde grillergewicht van een koppel, d.w.z. een hoger percentage is negatief want een minder uniform koppel) en mortaliteit;

(2) Database IKB-CRA met daarin de antibioticagebruiksgegevens, uitgedrukt in dierdagdosering per dierjaar, voor zowel opfok-, vermeerderings- als vleeskuikenkoppels;

(3) Database van het fokbedrijf, met daarin opgenomen productiekenmerken van de vermeerderingskoppels (o.a. aantal eieren, uitkomstpercentage, mortaliteit) gemiddeld over bepaalde leeftijdsperioden.

De gegevens werden met elkaar verbonden via de unieke combinatie van KIP-nummer van een koppel (vleeskuikens of moederdieren) en geboortedatum van een koppel (vleeskuikens of moederdieren).

De gegevens waren dus bekend op 3 niveaus, namelijk van opfokkoppel, vermeerderingskoppel en vleeskuikenkoppel (vleeskuikenkoppel op stalniveau, de andere gegevens op bedrijfsniveau). Bij analyse van consistente invloeden van de voorschakels (historie) beginnen we dus achteraan (vleeskuikenfase). Wanneer er duidelijk consistente invloeden van vermeerderingskoppel, vermeerderingsbedrijf of zelfs opfokbedrijf zijn, dan kan in de volgende fase worden onderzocht welke voorspellers correleren met laatstgenoemde consistente effecten.

\subsubsection{Aantal records}

$\mathrm{Na}$ het koppelen van de verschillende databases werden de volgende aantallen bruikbare records gevonden:

1598 Aantal records in vleeskuiken_productie_data (gegevens vleeskuikenkoppels op stalniveau) 
1546 Aantal records met identificatie koppel moederdieren (oftewel 52 records hebben geen bijpassend KIP-nummer en geboortedatum van de moederdieren)

1598 Aantal records ingevuld voor dierdagdosering antibioticum (hiervan waren 927 records met een dierdagdosering van 0, d.w.z. geen antibiotica toegepast)

1389 Records met informatie van de slachterij (groei, slachtkwaliteit, etc.) (oftewel van 209 records mist slachtinformatie)

Binnen deze 1598 records waren er 58 verschillende KIP-nummers van vleeskuikenbedrijven aanwezig, 70 KIP-nummers van vermeerderingsbedrijven en 154 verschillende vermeerderingskoppels (op 1546 records). In totaal bevatte de database voor analyse 1267 kuikenleveranties.

Het gemiddeld aantal records per vermeerderingskoppel (aantal kuikenleveranties van een vermeerderingskoppel waarvan de gegevens in de database voor analyse zaten) is gemiddeld slechts 10. Dit wordt o.a. veroorzaakt door leveranties die naar een andere slachterij zijn gegaan en daarom niet binnen de te analyseren keten bekend zijn.

\subsubsection{Materiaal en redenatie bij ordening van data richting fase van analyse}

Data afkomstig van verschillende bronnen (productiegegevens van het vermeerderingskoppel via het fokbedrijf, herkomst eieren en geboortedata kuikens via de vleeskuikenbroederij, herkomstgegevens en productiekenmerken van de vleeskuikenfase via slachterij, antibioticagebruiksgegevens via CRA database) zijn aan elkaar gekoppeld zodat één database is ontstaan waarin alle gegevens zijn opgenomen. Koppeling van gegevens uit de verschillende bronnen vond plaats door middel van KIP nummer (uniek bedrijfsnummer) en geboortedata.

De productiegegevens van de vermeerderingskoppels betroffen geaggregeerde data, waardoor er bijvoorbeeld geen gegevens per levensweek van het vermeederingskoppel beschikbaar waren maar alleen gemiddelden per kenmerk over een aantal levensweken. Dit heeft consequenties voor de analyse van waarde van informatie van voorschakels, zie ook hoofdstuk 4 - discussie. Van sommige geaggregeerde gegevens van vermeerderingskoppels waren er veel ontbrekende data, daarom is de analyse uitgevoerd met de volgende gegevens: uitkomst percentage op 60 weken, aantal uitgekomen eieren op 60 weken, aantal eieren op 30 weken, aantal eieren op 60 weken, koppelgrootte moederdieren en piekproductie (\%).

De volgende productiegegevens van de vleeskuikenkoppels werden meegenomen in de analyse: gemiddelde daggroei, groei index, afkeur, uniformiteit, uitval $1^{\mathrm{e}}$ week, uitval volledige productieperiode.

Antibiotica gebruiksgegevens van opfok, vermeerderings- en vleeskuikenkoppels werden verkregen via de IKB-CRA database en geregistreerd als dagdosering/dierjaar.

Bij het koppelen van de data bleek het erg lastig het juiste opfokkoppel bij het vermeerderingskoppel te vinden, vanwege het ontbreken van KIP (unieke bedrijfs) nummers die noodzakelijk zijn voor koppeling van gegevens. Uiteindelijk bleven er te weinig gegevens over van opfokkoppels om een betrouwbare analyse uit te voeren met opfokgegevens, deze is dus niet uitgevoerd.

\subsubsection{Analyse 1, schatting van gemiddelde effecten van seizoen, leeftijd moederdieren en tijdstrend, en daarnaast (simultaan) het schatten van variatiebronnen}

Voor het schatten van de vaste effecten van seizoen (via fourier-transformatie van kalenderdag zoals in Yassin, et al., 2009), leeftijd moederdieren (met behulp van woodcurve, zie Yassin, et al., 2009) en tijdstrend (lineair of kwadratisch), en daarnaast het simultaan schatten van variantiecomponenten (random coëfficiënten) bij kenmerken in de vleeskuikenfase is een gemengd (mixed) model gebruikt. De variantiecomponenten delen de totale (onverklaarde, dus na correctie voor de vaste effecten van seizoen, leeftijd moederdieren en tijdstrend) restvariantie op. Hierdoor worden de diverse bronnen van variatie op variantiebijdrage gekwantificeerd. Voor de kenmerken 'dierdagdoseringen', 'uitval', '\% 
uniformiteit' en '\% afkeuringen' is een logtransformatie $\ln \{y+0.5\}$ toegepast. Alleen bij het kenmerk '\% uniformiteit' is uiteindelijk een kwadratische tijdstrend toegepast. De fixed effecten zijn primair als correctiefactoren bedoeld en worden in geval van niet-significantie niet verwijderd uit het gemengde (eind)model.

Het model is als volgt:

$$
\underline{Y}_{i j k l m}=\beta_{0}+\beta_{1.1} * t+\beta_{1.2} * t^{2}+\beta_{2} * X_{1}+\beta_{3} * X_{2}+\beta_{4} *(A-1)+\beta_{5} * \ln (A)+\underline{\varepsilon}_{i}+\underline{\varepsilon}_{i j}+\underline{\varepsilon}_{k}+\underline{\varepsilon}_{k m}+\underline{\varepsilon}_{i k}+\underline{\varepsilon}_{i j k l}+\underline{\varepsilon}_{i j k l m}
$$

Met:

$\beta_{0}, \beta_{1.1}, \beta_{1.2} \quad$ : Intercept, lineaire term en kwadratisch term voor fixed tijdstrend in de periode :Tijd in dagen (vanaf $1^{\mathrm{e}}$ datum geboortedatum in dataset); t is maximaal 1087

$\beta_{2}, \beta_{3} \quad$ : Parameters voor seizoenseffect (na fourier transformatie van kalenderdagnummer, zie hieronder)

$X_{1}, X_{2} \quad: \operatorname{Sinus}\left(\frac{2 \pi}{365} * d\right), \operatorname{cosinus}\left(\frac{2 \pi}{365} * d\right)$, met $d$ als dagnummer in het jaar (op basis van geboortedatum vleeskuikens, dus van 1 tot 365 )

$\beta_{4}, \beta_{5} \quad$ : Parameters voor niet-lineaire curve voor invloed van leeftijd moederdieren

A : Leeftijd moederdieren, 3 weken voor geboorte vleeskuikens (in weken minus 18 (opfokperiode))

$\underline{\varepsilon}_{i}, \underline{\varepsilon}_{i j} \quad:$ Random effect van vermeerderingsbedrijf $i$, resp. vermeerderingskoppel $j$ (binnen $i$ )

$\underline{\varepsilon}_{k}, \underline{\varepsilon}_{k m} \quad$ : Random coëfficiënten van vleeskuikenbedrijf $k$, resp. vleeskuikenstal m (binnen $k$ )

$\underline{\varepsilon}_{i k} \quad:$ Random coëfficiënten van specifieke combinatie $i k$ van (vermeerderingsbedrijfvleeskuikenbedrijf)

$\underline{\varepsilon}_{i j k l}, \underline{\varepsilon}_{i j k l m} \quad:$ Random coëfficiënten kuikenleverantie (geboortedatum / binnen combinatie vermeerderingskoppel-vleeskuikenbedrijf), resp. specifieke combinatie van kuikenleverantie en vleeskuikenstal. Deze laatste is het niveau van een record

De gemiddelde effecten van seizoen, leeftijd-moederdieren en tijdstrend worden geschat. De resterende onverklaarde (dus na correctie voor seizoen, leeftijd-moederdieren en tijdstrend) variantie (ofwel Var $\{y\}$ ) kan worden opgedeeld naar de bronnen van variatie.

$\operatorname{Var}\{\mathrm{y}\}=\operatorname{Var}\{\mathrm{vb}$-bedrijf $\}+\operatorname{Var}\{\mathrm{vb}-$ koppel $\}+\operatorname{Var}\{\mathrm{vk}$-bedrijf $\}+\operatorname{Var}\{\mathrm{vk}$-stal $\}+$ Var $\{$ combinatie (vb-bedrijf; vk-bedrijf)\} $+\operatorname{Var}\{$ kuikenleverantie $\}+\operatorname{Var}\{$ combinatie(kuikenleverantie;vk-stal)\} 
Dus na correctie voor seizoen, leeftijd-moederdieren en tijdstrend schatten we:

Var\{vb-bedrijf\}: maat voor range, waarbinnen de bedrijfsgemiddelden van alle vb-bedrijven liggen. Var\{vb-koppel\}: maat voor de range, waarbinnen koppelgemiddelden van alle vb-koppels van eenzelfde vb-bedrijf liggen (een koppel is één of meerdere stallen op een vb bedrijf met dezelfde opzetdatum) $)^{1}$.

Var\{vk-bedrijf\}: maat voor range, waarbinnen de bedrijfsgemiddelden van alle vleeskuikenbedrijven liggen

Var $\{\mathbf{v k - s t a l \} : ~ m a a t ~ v o o r ~ r a n g e , ~ w a a r b i n n e n ~ d e ~ s t a l g e m i d d e l d e n ~ v a n ~ e e n z e l f d e ~ v l e e s k u i k e n b e d r i j f ~}$ ligt.

Var\{(combinatie (vb-bedrijf;vk_bedrijf\}: maat voor range, waarbinnen de afwijkingen (effecten) in verwachtingswaarde liggen bij specifieke combinaties van bedrijven uit 2 ketenschakels.

Var\{kuikenleverantie\}: maat voor range, waarbinnen de onverklaarde effecten van eenzelfde levering kuikens ligt.

Var\{(combinatie (kuikenleverantie;vk_stal\}: maat voor range van verschillen in prestatie, wanneer een levering kuikens op een vk-bedrijf wordt verdeeld over 2 stallen.

Het is zeer belangrijk om hierbij te realiseren dat:

- $\quad \operatorname{Var}\{$ kuikenleverantie\} en Var\{combinatie(kuikenleverantie;vk-stal)\} zijn gezamenlijk een soort "restvariantie". Dit is de variatie in kwaliteit van dieren van een individuele ronde in één vleeskuikenstal, welke niet te verklaren zijn door :

Gemiddeld seizoenseffect, gemiddeld effect van leeftijd_moederdieren, gemiddelde kwadratische tijdstrend, gemiddelde bedrijfseffecten van vermeerderingsfase en vleeskuikenfase, gemiddelde effect van specifieke combinatie van VB en VK (indien deze meer dan 1 keer voorkomt), gemiddelde vb-koppeleffecten en gemiddelde vk-staleffecten.

- De ratio (var\{kuikenleverantie\}) /(var\{kuikenleverantie $\}+$ var $\{$ (combinatie kuikenleverantie;vkstal)\}) geeft de geschatte correlatie (Fischer's Intra Class Correlatie) tussen vleeskuikenstallen op hetzelfde vleeskuikenbedrijf, opzet met dezelfde kuikens (exact dezelfde historie tot moment van aankomst op het vleeskuikenbedrijf).

\subsubsection{Analyse 2, relatie vleeskuikenkenmerken met productiekenmerken vermeerderingskoppels}

De consistente effecten van vermeerderingskoppel uit analyse 1 zijn naderhand gekoppeld aan productiekenmerken van deze vermeerderingskoppels (deze productiekenmerken komen uit een andere tabel, waar gegevens op niveau van vermeerderingskoppels zijn vastgelegd).

Zowel het succes van koppeling (bij hoeveel vermeerderingskoppels zijn beide vormen van informatie bekend) als de statistische samenhang van tussen productiekenmerken_vermeerderingsfase en vermeerderingskoppel_effecten_vleeskuikenfase zijn belangrijke vragen. Uitgangspunt in deze dataanalyse is dat er geen bewuste selectie bij gegevens heeft plaatsgevonden. Indien productiegegevens van vermeerderingskoppels ontbreken, dan beschouwen we dit voorlopig als missing ad random.

Voor analyse 2 is eenvoudige multipele regressie met wegingsfactor toegepast. Als responskenmerk ( $y$-variabele) geldt het vermeerderingskoppeleffect en de verschillende productiekenmerken van de vermeerderingskoppels gelden als $\mathrm{x}$-variabelen. Er zijn uitsluitend $\mathrm{x}$-variabelen gebruikt waarvan geen missende waarden waren.

Als wegingsfactor is het aantal bevolkte vleeskuikenstallen gebruikt. Hierdoor worden vermeerderingskoppeleffecten verschillend gewogen in analyse 2, afhankelijk van de hoeveelheid informatie in de vleeskuikenfase.

\footnotetext{
${ }^{1}$ N.b. bij vermeerderingsbedrijven worden gegevens niet op stalniveau vastgelegd, maar op niveau van alle stallen van één opzetdatum; een 'vb koppel' kan dus verwijzen naar één of meerdere stallen met gelijke opzetdatum. Bij vleeskuikenbedrijven worden de gegevens wel op stalniveau vastgelegd.
} 
De gebruikte $x$-variabelen zijn broederij, koppelgrootte moederdieren, aantal eieren op 30 weken, aantal op 60 weken, uitkomstpercentage op 60 weken, aantal uitgekomen eieren op 60 weken en piekproductie.

\subsubsection{Analyse 3, relatie vleeskuikenbedrijfseffecten en afstand broederij- vleeskuikenbedrijf}

Analyse 3 is wat betreft principe vergelijkbaar met analyse 2. In analyse 3 zijn de vleeskuikenbedrijfseffecten uit analyse 1 gekoppeld aan de afstanden tussen toeleverancier (broederij) en het vleeskuikenbedrijf zelf. Afstand tussen toeleverancier en vleeskuikenbedrijf is hiervoor gekozen omdat deze gegevens gemakkelijk te traceren waren en de duur van transport wellicht een rol kan spelen in de kuikenkwaliteit. Vervolgens is met behulp van lineaire regressie gekeken of de afstand (als $\mathrm{x}$-variabele) invloed heeft op de vleeskuikenbedrijfseffecten. Wederom met weging van het aantal bevolkte vleeskuikenstallen.

\subsection{Resultaten}

Van de 8 bekende vleeskuikenkenmerken zijn de globale (gemiddelde) invloeden van seizoen, leeftijd en tijdstrend (verloop over de jaren 2011-2014) geschat. In Tabel 3.1. wordt weergegeven of deze effecten signficant zijn voor de verschillende parameters. Behalve voor de kenmerken afkeuringspercentage en uitval $1^{\mathrm{e}}$ week, blijkt er een significante tijdstrend te zijn. Groei, eindgewicht en totale uitval vertonen een stijgende trend. Voor antibioticumgebruik is een dalende trend. De trend bij uniformiteit is complexer, na aanvankelijk daling zien we later weer een stijging (zie figuur 3.1).

Tabel 3.1 Significantie van schattingen voor effecten van tijdstrend, seizoen en leeftijd moederdieren per kenmerk op vleeskuikenniveau. + significant positief effect; - significant negatief effect; ns geen significant effect. Significantie niveau $P<0.05$.

\begin{tabular}{|c|c|c|c|c|c|c|}
\hline & $\begin{array}{c}\beta_{1.1} \\
\text { tijdstrend } \\
\text { (Iineair) }\end{array}$ & $\begin{array}{c}\beta_{1.2} \\
\text { tijdstrend } \\
\text { (kwadr.) }\end{array}$ & $\begin{array}{c}\beta_{2} \\
\text { seizoen } \\
\text { (sinus) }\end{array}$ & $\begin{array}{c}\beta_{3} \\
\text { seizoen } \\
\text { (cosinus) }\end{array}$ & $\begin{array}{c}\beta_{4} \\
\text { Lft_- } \\
\text { moederdieren } \\
\text { (Iineair) }\end{array}$ & $\begin{array}{c}\beta_{5} \\
\text { Lft_- } \\
\text { moederdieren } \\
\text { (loglineair) }\end{array}$ \\
\hline Groei & + & & ns & ns & ns & + \\
\hline Groei-index & + & & ns & ns & ns & + \\
\hline Eindgewicht & + & & ns & ns & ns & + \\
\hline $\begin{array}{l}\text { Perc. } \\
\text { Afkeuringen }\end{array}$ & ns & & + & + & ns & ns \\
\hline $\begin{array}{l}\text { Perc. } \\
\text { Uniformiteit }\end{array}$ & - & + & ns & + & ns & ns \\
\hline $\begin{array}{l}\text { Perc. uitval } \\
\text { week } 1\end{array}$ & ns & & ns & + & ns & ns \\
\hline $\begin{array}{l}\text { Perc. uitval } \\
\text { totaal }\end{array}$ & + & & + & + & ns & ns \\
\hline $\begin{array}{l}\text { Dagdoseringen } \\
A B\end{array}$ & - & & ns & ns & ns & ns \\
\hline
\end{tabular}




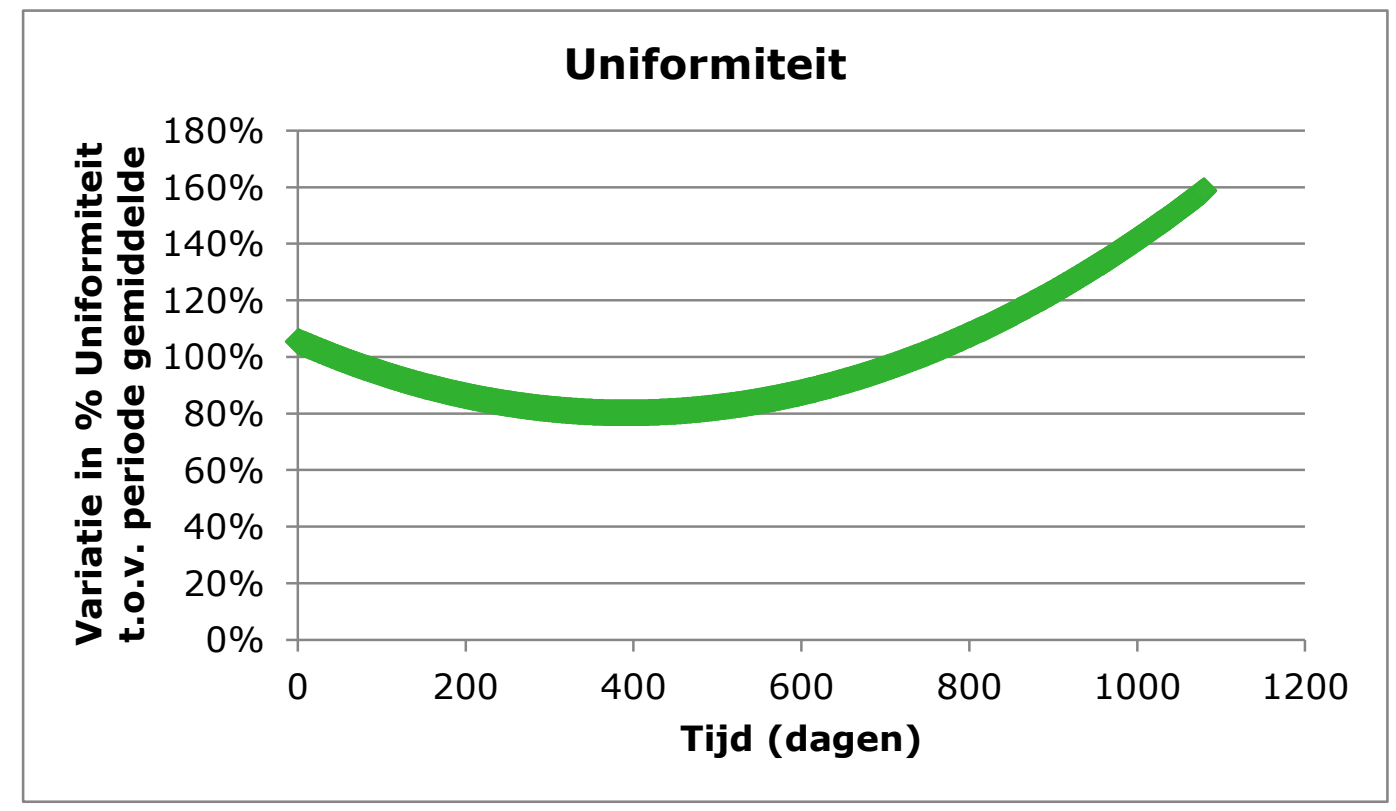

Figuur 3.1 Tijdstrend in kenmerk \% uniformiteit (100\% is periode-gemiddelde van de geanalyseerde jaren).Tijd ( $X$-as) is het aantal dagen van de geanalyseerde jaren, dus dag 0 is 1-1-2011.

De kenmerken uitval 1e week en uitval totaal, percentage afkeuringen aan de slachtlijn en percentage uniformiteit vertonen een significante invloed van seizoen. Doorgaans zien we hier met name een verschil tussen zomer en winter (parameter $\beta_{2}$ in Tabel 3.1). In figuur 3.2 wordt het de seizoensinvloed op het percentage afkeuringen aan de slachtlijn weergeven. Hieruit blijkt dat in de winter (rond dag 40) het percentage afkeuringen het hoogst is en in de zomer (rond dag 200) het percentage afkeuringen het laagst is. Figuur 3.3. geeft de seizoensinvloed op het percentage uitval in de eerste week en totale uitval op het vleeskuikenbedrijf. Uit Figuur 3.3. blijkt dat de eerste weeks en totale uitval het laagst zijn rond de zomer (rond dag 200) en het hoogst in de winterperiode (rond dag 40).

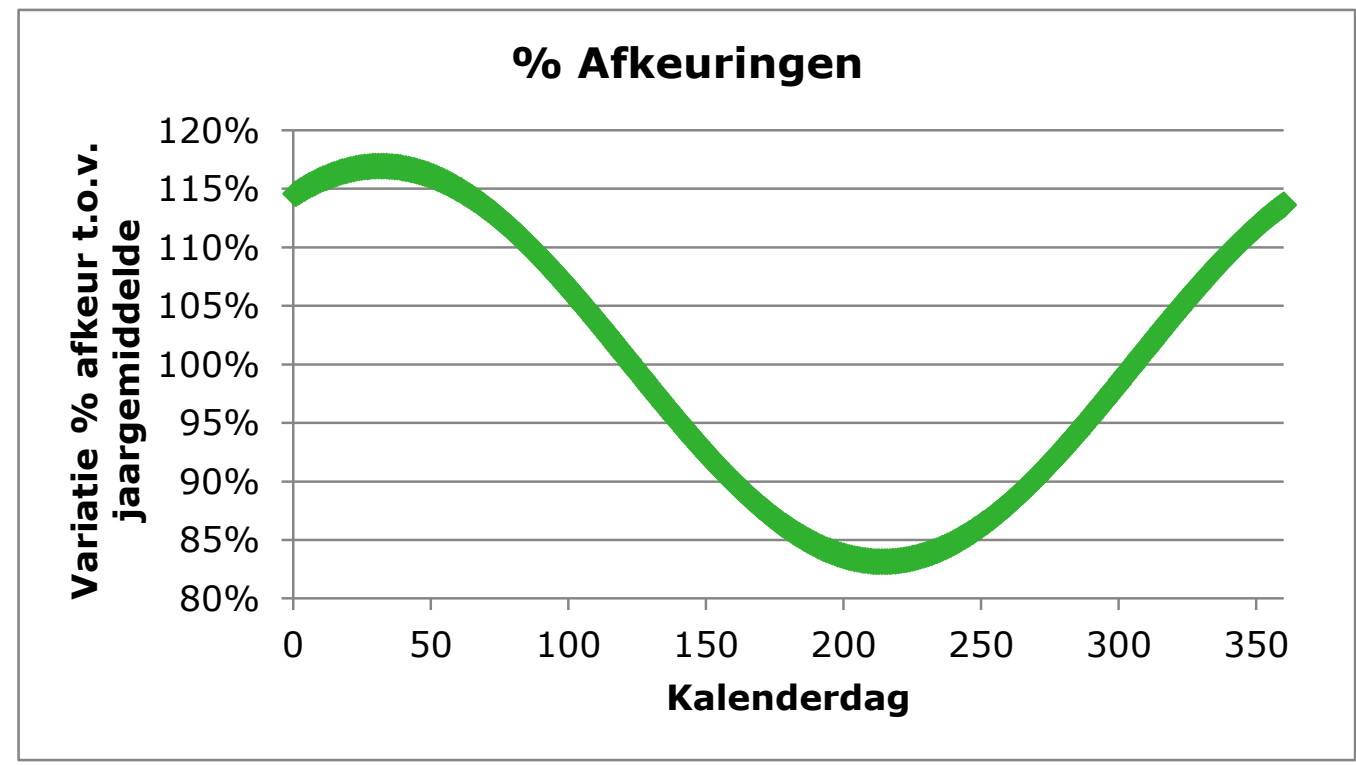

Figuur 3.2 Seizoensinvloed (kalenderdag weergegeven op de $X$-as, dag in aantal na 1 januari) in kenmerk percentage afkeuringen (100\% is gemiddelde over een volledig jaar). 

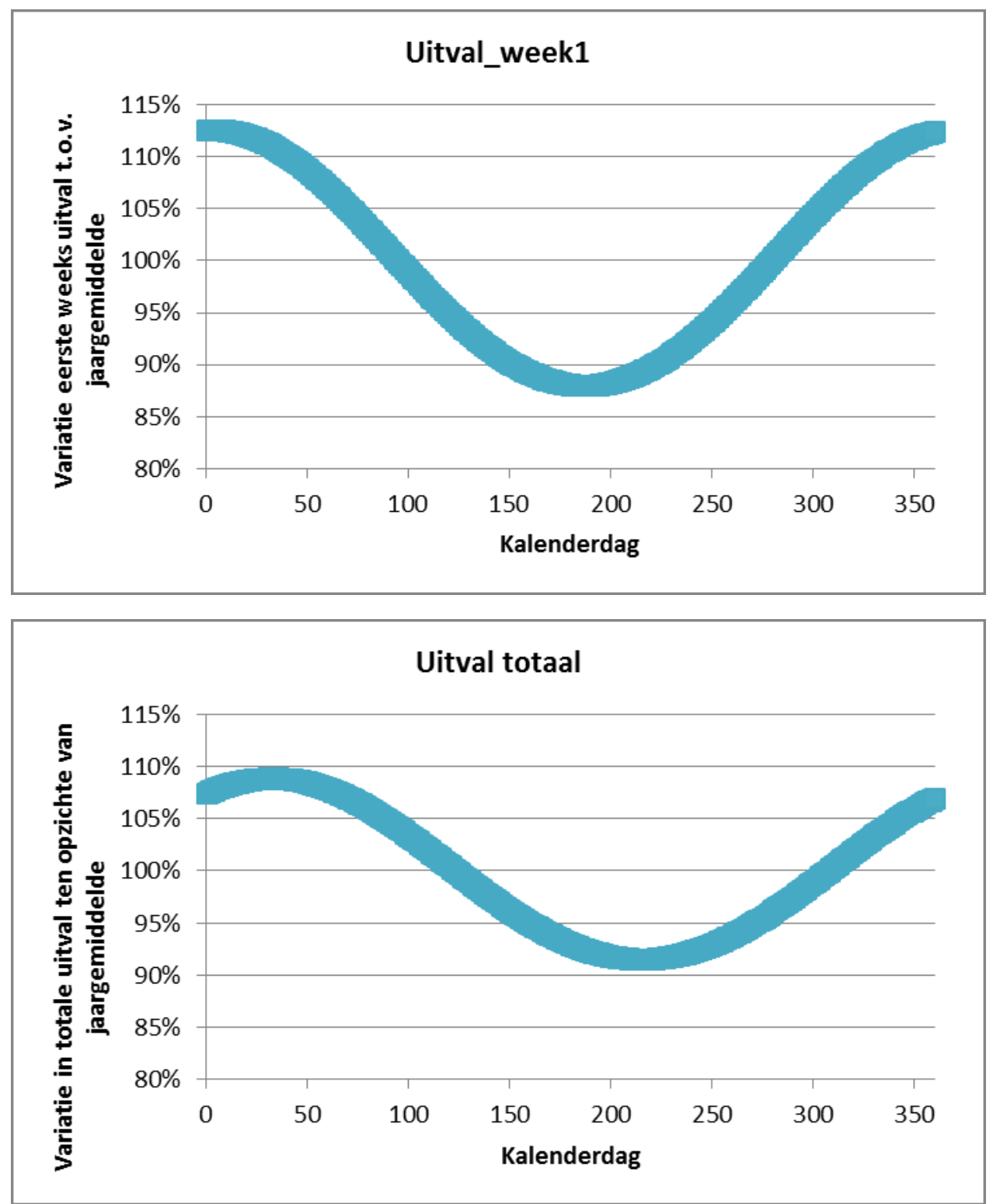

Figuur 3.3 Seizoensinvloed (kalenderdag weergegeven op de $X$-as, dag in aantal na 1 januari) in kenmerk percentage eerste weeks uitval (bovenste figuur) en totale uitval (onderste figuur) (100\% is periode-gemiddelde).

Zowel groei als eindgewicht worden significant beïnvloed door leeftijd van de moederdieren (zie Tabel 3.1. en ook Figuur 3.4.). De term parameter $\beta_{5}$ in Tabel 3.1. geeft de invloed van de leeftijd in het eerste deel van de productiefase van de moederdieren weer; de significantie van juist deze term geeft aan dat het effect van leeftijd van de moederdieren vooral in de eerste fase van productie geldt (hele jonge moederdieren geven lagere groei bij vleeskuikens). In figuur 3.4 wordt de invloed van leeftijd van de moederdieren op de groei-index weergegeven. 


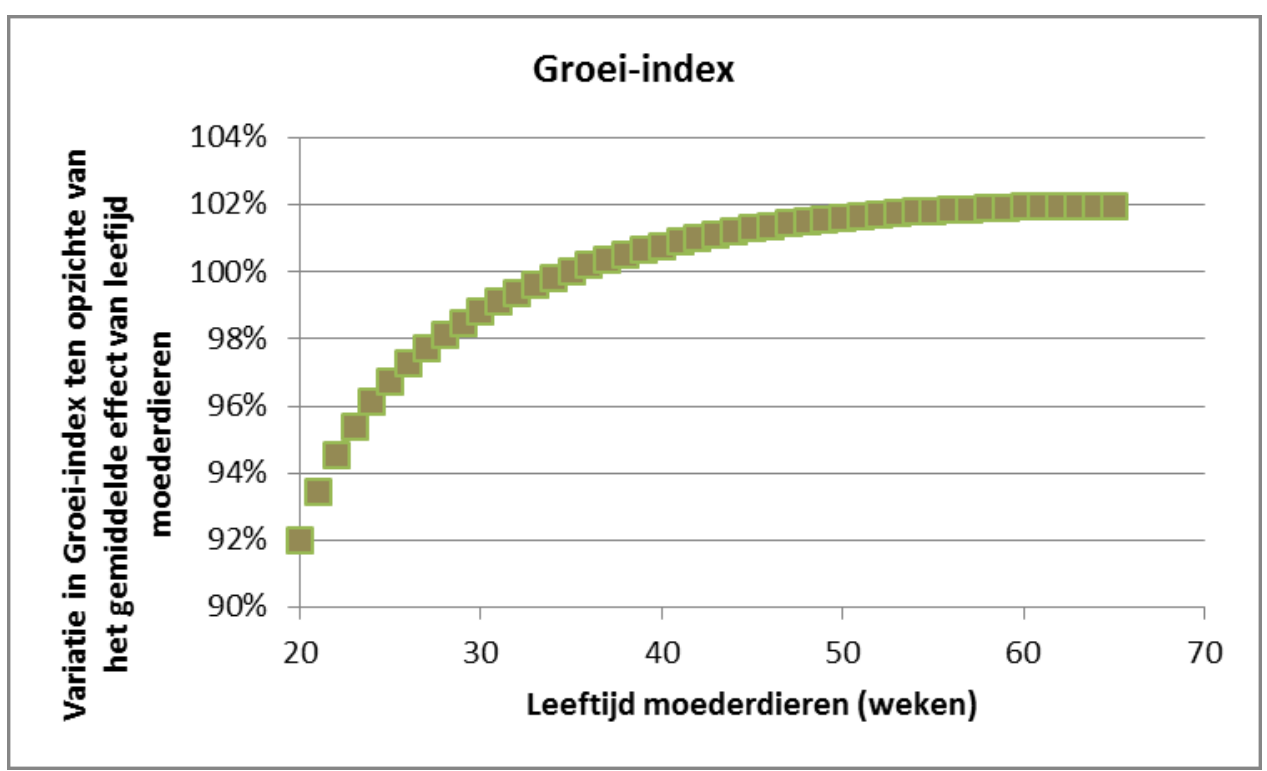

Figuur 3.4 Verloop groei-index tegen leeftijd (in weken) van de moederdieren (100\% is gemiddelde van leeftijd moederdieren).

\subsubsection{Variantiecomponenten}

In tabel 3.2 staan de variantiecomponenten opgenomen. Aangezien het hier om varianties gaat, is het belangrijk om te realiseren dat het hier om kwadraten gaat. Het lijkt zinvol om dit zowel kwalitatief (waar zit meer variantie, en dus invloed) als kwantitatief (hoeveel verschil mag ik nu tussen de uitersten binnen een categorie verwachten) te behandelen.

Tabel 3.2 Schattingen voor relatieve grootte van de variantiecomponenten. VM: vermeerderingsbedrijf; VK: vleeskuikenbedrijf; KL: 'kuikenleverantie'; SKL: 'stal binnen kuikenleverantie, zie voetnoot voor toelichting.

\begin{tabular}{|c|c|c|c|c|c|c|c|c|}
\hline & $\begin{array}{l}\underline{\varepsilon}_{i} \\
\text { Bedrijfs- } \\
\text { effect }\end{array}$ & $\begin{array}{l}\underline{\varepsilon}_{i j} \\
\text { Koppel- } \\
\text { effect }\end{array}$ & $\begin{array}{l}\underline{\varepsilon}_{k} \\
\text { Bedrijfs- } \\
\text { effect }\end{array}$ & $\begin{array}{l}\underline{\varepsilon}_{k m} \\
\text { Stal- } \\
\text { effect }\end{array}$ & $\begin{array}{l}\underline{\varepsilon}_{i k} \\
\text { Specifieke } \\
\text { Combinatie }\end{array}$ & $\begin{array}{l}\underline{\varepsilon}_{i j k l} \\
\text { Kuiken- } \\
\text { leverantie }\end{array}$ & $\begin{array}{l}\underline{\mathcal{E}}_{i j k l m} \\
\text { Stal } \\
\text { binnen }\end{array}$ & $\begin{array}{l}\text { Fisher's } \\
\text { ICC }^{1}\end{array}$ \\
\hline & VM & VM & VK & VK & VM x VK & KL & KL & \\
\hline & & & & & & & SKL & \\
\hline Groei & $0 \%$ & $3 \%$ & $41 \%$ & $1 \%$ & $3 \%$ & $36 \%$ & $16 \%$ & 0.69 \\
\hline Groei-index & $0 \%$ & $3 \%$ & $57 \%$ & $2 \%$ & $2 \%$ & $25 \%$ & $10 \%$ & 0.72 \\
\hline Eindgewicht & $0 \%$ & $5 \%$ & $34 \%$ & $0 \%$ & $0 \%$ & $43 \%$ & $19 \%$ & 0.69 \\
\hline \%Afkeuringen & $1 \%$ & $8 \%$ & $11 \%$ & $1 \%$ & $0 \%$ & $36 \%$ & $44 \%$ & 0.45 \\
\hline$\%$ Uniformiteit & $0 \%$ & $9 \%$ & $21 \%$ & $4 \%$ & $0 \%$ & $32 \%$ & $34 \%$ & 0.49 \\
\hline \% Uitval week1 & $0 \%$ & $6 \%$ & $16 \%$ & $0 \%$ & $0 \%$ & $39 \%$ & $38 \%$ & 0.51 \\
\hline \% Uitval totaal & $0 \%$ & $6 \%$ & $31 \%$ & $1 \%$ & $0 \%$ & $38 \%$ & $25 \%$ & 0.60 \\
\hline Dagdoseringen & $0 \%$ & $2 \%$ & $16 \%$ & $0 \%$ & $0 \%$ & $48 \%$ & $34 \%$ & 0.58 \\
\hline
\end{tabular}

AB-gebruik

1: Fisher's ICC geeft de correlatie tussen prestaties van vleeskuikens in twee stallen op hetzelfde bedrijf, met kuikens van dezelfde levering (dus afkomsting van dezelfde VB).

2: Kolommen KL en SKL geven de relatieve variantie in kwaliteit van slachtkuikens van een individuele ronde in één vleeskuikenstal, welke niet te verklaren zijn door:

Gemiddeld seizoenseffect, gemiddeld effect van leeftijd_moederdieren, gemiddelde kwadratische tijdstrend, gemiddelde bedrijfseffecten van vermeerderingsfase en vleeskuikenfase, gemiddelde effect van specifieke combinatie van VB en VK (indien deze meer dan 1 keer voorkomt), gemiddelde vb-koppeleffecten en gemiddelde vk-staleffecten.

De resultaten in Tabel 3.2. geven aan dat na correctie voor invloeden van seizoen, leeftijd moederdieren en tijdstrend er vrijwel geen constante verschillen (invloeden) tussen vermeerderingsbedrijven aanwezig zijn. In andere woorden, uit deze analyse komt niet naar voren dat een vermeerderingsbedrijf constant beter of slechter heeft gepresteerd dan de andere 
vermeerderingsbedrijven voor een bepaald kenmerk. Uitzondering hierop is het kenmerk percentage afkeuringen van de vleeskuikens, hoewel deze variantiecomponent hier nog steeds relatief klein is (ong. $1 \%$ van de totale variantie).

De relatieve omvang van de variantiecomponenten voor het effect van vermeerderingskoppel is relatief gering $(<10 \%)$, waarbij de kenmerken 'afkeuringen' en 'uniformiteit' hier het hoogst scoren.

Verder lijkt er op basis van deze analyse geen sprake van grote constante staleffecten ( $\underline{\varepsilon}_{k m}$ in Tabel 3.2) op een vleeskuikenbedrijf.

Uit deze analyse blijken ook geen sterke aanwijzingen voor afwijkende (betere of juist slechtere) prestatie bij specifieke combinaties van vermeerderingsbedrijf en vleeskuikenbedrijf. Al moet hier wel worden vermeld dat de data niet zodanig waren dat we dit goed kunnen onderzoeken. Het herhaald voorkomen van dezelfde combinatie van vermeerderaar en vleeskuikenhouder is vrij gering in de huidige dataset. Wel is het opvallend dat juist de groeikenmerken hier oplichten.

De variantiecomponenten voor vleeskuikenbedrijf, kuikenleverantie en stal x kuikenleverantie zijn bij alle kenmerken relatief groot.

In bijlage 2 staan alle variantiecomponenten weergeven. Om een indruk van krijgen van de verschillen in de praktijk zijn de 2 meest extreme vermeerderingskoppels (in dit geval voor het kenmerk groeiindex) nagezocht in de data en in figuur 3.5 gevisualiseerd. Ieder stipje in deze grafiek is een combinatie van vleeskuikenstal en kuikenleverantie. De ruwe gemiddelden van de groei-index van beide vermeerderingskoppels verschillen 14.5 punten (130.5 voor het beste respectievelijk 116 voor het slechtste vermeerderingskoppel). Dit komt goed overeen met de verwachting op basis van de geschatte variantiecomponenten.

Met behulp van de geschatte variantiecomponenten schatten we een 3s-betrouwbaarheidsinterval van 11.3 punten. Dit wil dan zeggen dat ruim $99 \%$ van de vermeerderingskoppels in een bandbreedte van 11.3 punten zitten. Het ruwe gemiddelde kan hier nog altijd iets van verschillen, omdat bij de ruwe gemiddelde niet is gecorrigeerd voor fixed effecten (bijv. tijdstrend) en het gemiddelde kwaliteitsniveau van de vleeskuikenbedrijven.

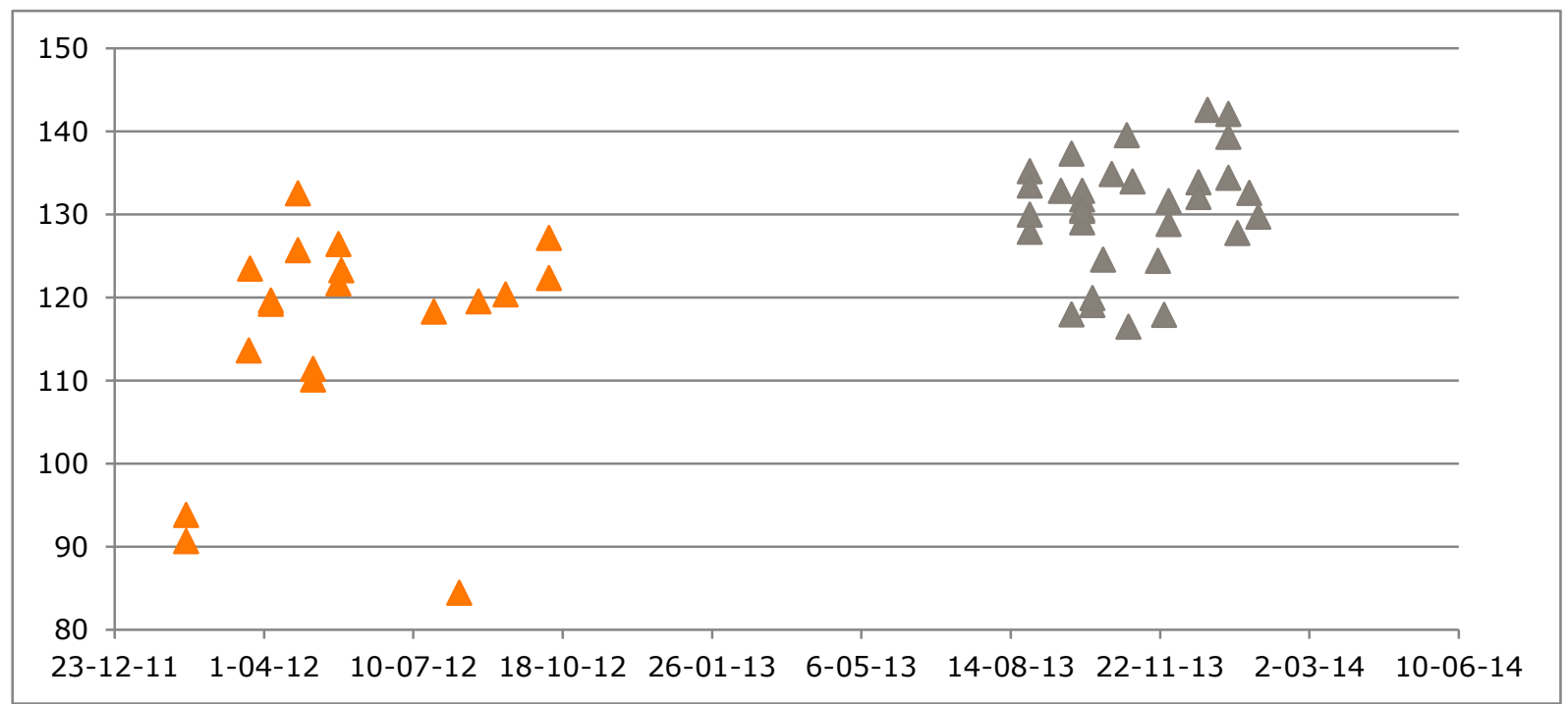

Figuur 3.5 Visualisatie van prestaties van vleeskuikens van 2 meest extreme vermeerderingskoppels voor kenmerk groei-index ( $Y$-as), uitgezet tegen geboortedatum kuikens op de $X$-as. Ieder driehoekje in de grafiek representeert de groei-index van een koppel vleeskuikens, waarbij driehoekjes in een kleur afkomstig zijn van hetzelfde vermeerderingskoppel.

In figuur 3.6 zijn de koppeleffecten van alle 154 vermeerderingskoppels per kenmerk (allemaal gemeten bij de vleeskuikens) tegen elkaar uitgezet. Hierdoor is te zien hoe koppeleffecten van verschillende kenmerken aan elkaar gerelateerd zijn. Groei en groei-index hebben logischerwijs een 
grote correlatie hebben omdat de groei-index een afgeleide van groei is. Extreme koppels voor een bepaald kenmerk zijn terug te vinden, maar mogelijk is het ook interessant om te kijken of een vermeerderingskoppel juist extreem is, wanneer 2 kenmerken tegelijk worden beschouwd. Dit zijn de punten buiten de donkere puntenwolk en dit niet in het verlengde van de gemiddelde relatie tussen 2 kenmerken liggen. De combinatie van koppeleffecten van groei-index (grI) en antibioticumgebruik (dd) vertoont een grote verscheidenheid. Een hoog koppeleffect voor groei-index gaat bij sommige vermeerderingskoppels gepaard met een laag koppeleffect voor antibioticumgebruik, maar er zijn ook koppels waarbij een hoog koppeleffect juist gepaard gaat met een hoog koppeleffect voor antibioticumgebruik.

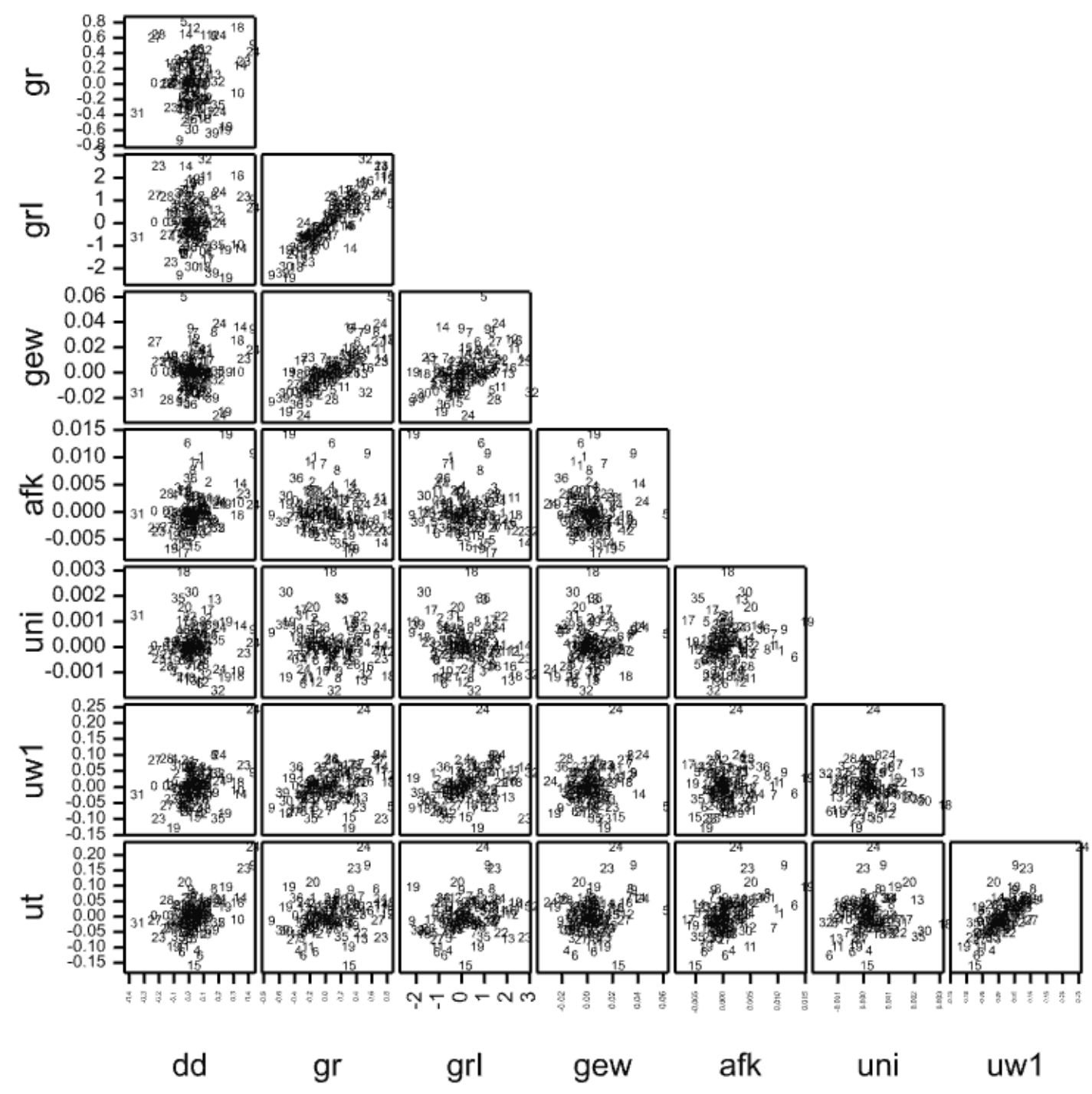

Figuur 3.6 Visualisatie alle effecten van de 154 vermeerderingskoppels voor alle kenmerken.dd: dierdagdosering antibiotica; gr: daggroei; grI: groei Index; gew: slachtgewicht; afk: afkeur; uni: uniformiteit; uw1: uitval $1^{e}$ levensweek. De symbolen in de figuurtjes geven het aantal vleeskuikenstallen weer dat is opgezet met vleeskuikens van dezelfde VB-koppel. Voor nadere toelichting zie 3.3.1.

\subsubsection{Resultaten analyse 2: relatie vleeskuikenkenmerken met productiekenmerken vermeerderingskoppels}

De resultaten van analyse 2 , de relatie tussen vleeskuikenkenmerken en productiekenmerken van vermeerderingskoppels worden weergegeven in Tabel 3.3. 
Tabel 3.3 Schattingen voor statistische samenhang tussen vb-koppeleffecten (o.b.v. productie van alle in de dataset aanwezige vleeskuikenkoppels van deze vb-koppels) met de (eigen productie-) kenmerken van deze vb-koppels.

\begin{tabular}{|c|c|c|c|c|c|c|c|}
\hline & broederij & $\begin{array}{l}\text { Uitkomst } \\
\text { percentag } \\
\text { e op } 60 \\
\text { weken }\end{array}$ & $\begin{array}{l}\text { Aantal } \\
\text { uitgekomen } \\
\text { eieren op } 60 \\
\text { weken }\end{array}$ & $\begin{array}{l}\text { Aantal } \\
\text { eieren op } \\
30 \text { weken }\end{array}$ & $\begin{array}{l}\text { Aantal } \\
\text { eieren op } \\
60 \text { weken }\end{array}$ & $\begin{array}{l}\text { Koppel- } \\
\text { grootte } \\
\text { moeder- } \\
\text { dieren }\end{array}$ & $\begin{array}{l}\text { Piek } \\
\text { productie }\end{array}$ \\
\hline Groei & ns & ns & ns & ns & ns & ns & ns \\
\hline Groei-index & ns & ns & ns & ns & ns & ns & ns \\
\hline Eindgewicht & ns & ns & ns & ns & ns & ns & ns \\
\hline \%Afkeuringen & ns & ns & ns & ns & ns & ns & $--\left({ }^{0}\right)$ \\
\hline$\%$ Uniformiteit ${ }^{1}$ & ns & $+(*)$ & $+(*)$ & ns & $+(*)$ & ns & $+(*)$ \\
\hline \%Uitval_week1 & ns & ns & ns & ns & $--(*)$ & $+\left({ }^{\circ}\right)$ & ns \\
\hline \%Uitval totaal & ns & ns & ns & ns & $--(*)$ & ns & ns \\
\hline Dagdoseringen & ns & ns & ns & ns & ns & ns & ns \\
\hline
\end{tabular}

$A B$

$\left({ }^{\circ}\right): p<0.10 ;(*): p<0.05 ;+$ positieve correlatie; -- negatieve correlatie

${ }^{1}$ Een hoger \% uniformiteit betekent minder uniforme kuikens. Een positieve correlatie met \% uniformiteit betekent hier dat minder uniform vleeskuikenkoppel aan de slachtlijn samengaat met een hogere piekproductie, hoger uitkomst\% op 60 weken, meer uitgekomen eieren op 60 weken en meer eieren op 60 weken leeftijd.

Er zijn enkele statistisch significante verbanden gevonden. Het vb-koppel-effect van de moederdieren voor het kenmerk \%Uniformiteit van de slachtkuikens blijkt positief gecorreleerd met diverse productiekenmerken van de moederdieren (Uitkomst\%_week60, Aantal eieren leeftijd week 30 resp. 60 en ook piekproductie). Aantal eieren op 60 weken is negatief gecorreleerd met uitval van de kuikens (zowel in week1 als totale uitval). Tot slot nog 2 relaties die een statistische trend $(P<0.10)$ geven, te weten :

- $\quad$ positieve correlatie tussen koppelgrootte van de moederdieren en uitval $1^{\mathrm{e}}$ week van de kuikens.

- $\quad$ negatieve correlatie tussen piekproductie van de moederdieren en \% afkeuringen bij de vleeskuikens op de slachterij.

\subsubsection{Resultaten analyse 3: relatie afstand broederij-vleeskuikenbedrijf met vleeskuikenbedrijfseffect}

Geen van de bedrijfseffecten van de vleeskuikenbedrijven vertoonde een significante correlatie met de afstand van het vleeskuikenbedrijf tot de broederij. Het kenmerk Uniformiteit had een p-waarde van 0.13 en komt in de buurt van een statistische tendens. Opvallend is het vleeskuikenbedrijf op een afstand van ruim $200 \mathrm{~km}$ met het laagste bedrijfseffect voor uniformiteit. De relatie tussen de uniformiteit en de afstand tussen broederij en vleeskuikenbedrijf wordt gevisualiseerd in Figuur 3.6. 


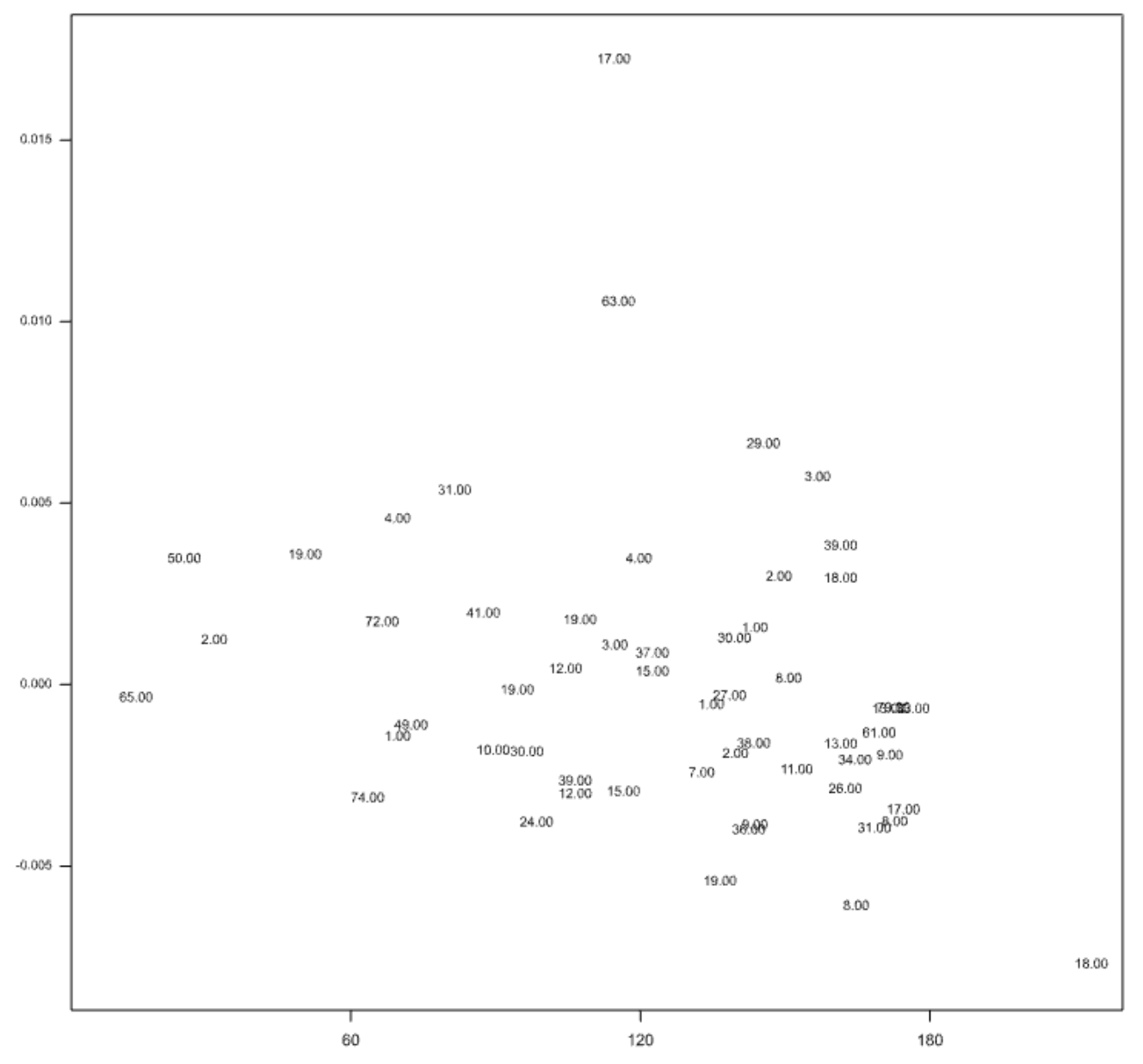

Figuur 3.6 Het vleeskuikenbedrijfseffect voor uniformiteit ( $y$-as) uitgezet tegen de afstand tussen vleeskuikenbedrijf en broederij (getal geeft het aantal keer dat een vleeskuikenstal op het betreffende vleeskuikenbedrijf is bevolkt met nieuwe kuikens). 


\section{Beknopte literatuurstudie}

Dit hoofdstuk is een beknopte weergave van de literatuur met betrekking tot verbanden tussen gebeurtenissen, factoren of kenmerken van de voorschakel en gezondheid, welzijn of technische prestatie van vleeskuikens.

\subsection{Analyse ketendata en mogelijke verbanden}

Yassin et al. (2008, 2009) analyseerden standaard vastgelegde gegevens op niveau van de broederij (gegevens van twee commerciële Nederlandse vleeskuikenbroederijen in de periode 2004-2006) en de mogelijke relatie tussen deze gegevens en het uitkomstpercentage en de eerste weeks uitval van vleeskuikens. Uit dat onderzoek bleek dat leeftijd moederdieren, de bewaarduur van de eieren, seizoen, voerfabriek van de ouderdierkoppels, ras en broederij allemaal van invloed waren op het uitkomstpercentage van de eieren en de uitval in de eerste week. Daarnaast werd gevonden dat er significante verschillen waren in de uitval in de eerste week tussen koppels moederdieren en tussen koppels vleeskuikens binnen een vleeskuikenbedrijf (Yassin, et al., 2009). Voor het

uitkomstpercentage waren er ook significante verschillen tussen koppels moederdieren (Yassin et al., 2008). Koppels vleeskuikens van jonge moederdieren hadden de hoogste uitval en ook aan het einde van de productieperiode nam de uitval weer toe (maar bleef gemiddeld lager dan bij koppels van jonge moederdieren) (Yassin, et al., 2008). De uitkomstpercentages waren het laagst bij oude moederdieren en in mindere mate lager bij jonge moederdieren, en het hoogst tussen 31 en 36 weken leeftijd (Yassin, et al., 2008). In het algemeen nam de uitval ook toe en het uitkomstpercentage af naarmate de bewaarduur van de eieren op de broederij toenam, maar was de mate waarin de uitval toenam wel afhankelijk van de broederij. De hoogste uitval werd gevonden tussen medio maart en medio april, en de laagste uitval tussen medio september en medio oktober (Yassin, et al., 2009). De verschillen tussen koppels moederdieren werden door Yassin, et al. (2009) verklaard door mogelijke verschillen in management op de vermeerderingsbedrijven; de verschillen tussen vleeskuikenbedrijven en tussen stallen binnen een vleeskuikenbedrijf werden door Yassin, et al. (2009) verklaard door mogelijke verschillen in omstandigheden waarin de kuikens werden opgevangen op het vleeskuikenbedrijf in de eerste week. Wat betreft uitkomstpercentage werden de verschillen tussen moederdierenkoppels groter naarmate de leeftijd vorderde, wat impliceert dat mogelijk met aangepast management op vermeerderingsbedrijven de uitkomstpercentages nog verbeterd kunnen worden (Tona, et al., 2007; Yassin, et al, 2008).

De effecten van voerfabrikant van de vermeerderingsbedrijven op uitval in de eerste week bij de vleeskuikens werden bediscussieerd in het licht van mogelijke effecten van voeding van het moederdier op het embryo via de samenstelling van het ei (Yassin, et al., 2009). Dit wordt in de volgende paragraaf verder besproken.

Uit epidemiologisch onderzoek naar het voorkomen van voetzoollaesies bij Nederlandse koppels vleeskuikens en mogelijke risicofactoren voor het optreden van voetzoollaesies bleek dat de factor 'broederij' een belangrijke invloed had op de mate waarin voetzoollaesies voorkwamen. Echter, in dat onderzoek was het niet mogelijk meer specifiek te kijken naar eventuele onderliggende factoren die het broederij effect konden verklaren, waardoor het niet duidelijk was of het in dit geval ging om de invloed van broedcondities, of om bijvoorbeeld de invloed van condities op vermeerderingsbedrijven die waren verstrengeld met broederij, zoals bijvoorbeeld de voeding van de moederdieren (de Jong, et al., 2012b). In een vervolgonderzoek werden kuikens afkomstig uit eieren van hetzelfde vermeerderingsbedrijf gebroed bij twee broederijen en vervolgens geplaatst onder gelijke omstandigheden in één stal. Kuikens van één broederij presteerden significant beter, terwijl er een numeriek verschil werd gevonden voor voetzoollaesies. Dit numerieke verschil in voetzoollaesies kwam overeenmet het voorafgaande onderzoek (de Jong, et al., 2015). Deze resultaten geven aan dat 
verder onderzoek naar een mogelijk effect van broedomstandigheden en mogelijke verstrengeling met de voorschakels (bijvoorbeeld voerfabrikant) noodzakelijk is.

\subsection{Transgenerationele effecten}

Volgens Berghof et al. (2013) zijn er aanwijzingen dat er sprake is van transgenerationele effecten op de aangeboren afweer van vleeskuikens. In hun review artikel worden 'transgenerationele epigenetische effecten' gedefinieerd als 'effecten die op niet-genetische wijze worden overgedragen tussen het moederdier (vleeskuikenouderdier) en de nakomelingen (vleeskuikens)'. Dit betekent dat het vleeskuiken van de ouders meekrijgt hoe het moet functioneren in de te verwachten omgeving. Op het moment dat er een 'mismatch' is tussen de omgeving van het moederdier en van de nakomeling (vleeskuiken) kan er dus sprake zijn van ongewenste effecten van het moederdier op de nakomelingen. In hun review geven Berghof et al. (2013) aan dat er tot nu toe nog weinig onderzoek is uitgevoerd naar mogelijke transgenerationele epigenetische effecten van gebeurtenissen of factoren in het leven van vleeskuikenouderdieren op de aangeboren immuniteit bij het vleeskuiken, terwijl een dergelijk mechanisme wel van belang is omdat een vleeskuiken voor een groot deel van de afweer afhankelijk is van juist de aangeboren afweer.

Er zijn enkele voorbeelden bekend uit de literatuur waar sprake is van bovengenoemde transgenerationele epigenetische effecten bij vleeskuikenouderdieren. Van der Waaij et al. (2011) hebben moederdieren op een leeftijd van 60 weken gedurende vijf weken onbeperkt gevoerd of gevoerd volgens het standaard (beperkte) voerschema, en de nakomelingen (vleeskuikens) op een onbeperkt of beperkt voerschema laten opgroeien. Uit dit onderzoek bleek dat nakomelingen (met name de haantjes) van moederdieren die beperkt werden gevoerd minder zwaar waren op zes weken leeftijd dan nakomelingen van moederdieren die onbeperkt werden gevoerd. Dit kwam door minder spiermassa in deze kuikens. Onbeperkt voeren van de moederdieren resulteerde in meer buikvet in de hennetjes op zes weken leeftijd. Uit dit onderzoek kwamen dus aanwijzingen naar voren voor mogelijke transgenerationele epigenetische effecten bij vleeskuikens.

Enting et al. (2007) toonden aan dat het energiegehalte van het voer van vleeskuikenmoederdieren in de productiefase een effect had op de embryonale ontwikkeling via de ei samenstelling. Moederdieren gevoerd met een laag energie voer ( $11 \%$ minder energie) in de opfokperiode kwamen later aan de leg en hadden een hogere eiproductie en zwaardere eieren dan moederdieren gevoerd met standaard voer, maar een lager uitkomstpercentage. Bij moederdieren gevoerd met voer met $21 \%$ minder energie was er sprake van een hoger embryogewicht en betere orgaanontwikkeling van de embryo's. Uit onderzoek van Van Emous et al. (2015a) bleek dat voer met een standaard energiegehalte vergeleken met voer met zowel een hoog- als een laag-energie gehalte tijdens het eerste deel van de productiefase leidde tot een lagere broedeiproductie. Voer met een hoog energiegehalte in de tweede fase van de legperiode zorgde uiteindelijk voor een hoger uitkomstpercentage en minder tweede soort kuikens. Uit deze studies blijkt dat het energiegehalte van het moederdierenvoer dus van invloed kan zijn op de eiproductie en uitkomstpercentages, maar verder onderzoek is nodig. Zo verschilden deze studies niet alleen in het type moederdier, maar ook in voersamenstelling en voergift per leeftijdsfase.

Naast het energiegehalte is het eiwitgehalte van het moederdierenvoer van invloed op onder andere de bevruchtings- en uitkomstpercentages. Van Emous et al. (2015a) lieten zien dat een laag eiwitgehalte tijdens de opfokperiode de embryonale sterfte tijdens de eerste helft van de productieperiode verlaagde en de broedeiproductie tijdens de tweede fase van de productieperiode verhoogde. In een ander experiment van Van Emous et al. (2015b) werden vleeskuikenmoederdieren tijdens de opfokperiode zodanig gevoerd dat ze een standaard of hoger lichaamsgewicht bereikten op 22 weken leeftijd, en daarnaast werden er drie verschillende niveaus van ruw eiwit toegepast tijdens de opfokperiode. Uit dit onderzoek kwam naar voren dat bevruchtings- en uitkomstpercentage van eieren van jonge moederdieren ( 29 weken leeftijd) met het hoge groeipatroon tijdens de opfokperiode (hoogste gewicht op 22 weken) significant waren verhoogd en de nakomelingen beter presteerden. Ook was er een effect van het ruw eiwitgehalte: vleeskuikens van moederdieren met gemiddeld of hoog ruw eiwitgehalte in het voer hadden de hoogste voeropname tussen 18 en 27 dagen leeftijd, en 
mannelijke vleeskuikens van moederdieren gevoerd met het laag eiwitniveau hadden het hoogste percentage borstvlees (van Emous, et al., 2015b).

Een ander voorbeeld is afkomstig van jonge vleeskuikenmoederdieren die een voer kregen met een relatief laag niveau van vitaminen en mineralen of een voer met een relatief hoog niveau van vitaminen en mineralen. In dit onderzoek werd een effect gezien van de voersamenstelling op genexpressie in de darmen en een effect op het immuunsysteem bij de nakomelingen op 3 en 14 dagen leeftijd. De genen waarvan de expressie was veranderd waren gerelateerd aan darmontwikkeling en proliferatie, metabolisme en absorptie van nutriënten. Ook werd de proliferatie van de dunne darm gemeten in de nakomelingen, die inderdaad verschilde tussen beide proefgroepen. Er werd echter geen verschil in groei of voederconversie gemeten tussen nakomelingen van beide proefgroepen (Rebel, et al., 2006). Voer verrijkt met omega-3 vetzuren bij vleeskuikenmoederdieren had echter maar een gering effect op de immuunrespons van de nakomelingen (Koppenol, et al., 2015).

De mogelijke effecten van voersamenstelling van moederdieren en vaderdieren op de ontwikkeling van het embryo en de prestatie van de nakomelingen worden samengevat en bediscussieerd door Chang et al. (2016). De auteurs geven aan dat met name het ruw eiwitgehalte en het energiegehalte in het voer van de ouderdieren van belang lijkt te zijn en dat effecten daarvan mogelijk terug te vinden zijn in een betere kuikenkwaliteit, hoger kuikengewicht, een lagere mortaliteit, een betere immuunrespons, betere strooiselkwaliteit en een betere groei. Het lijkt dat mannelijke nakomelingen een grotere respons vertonen op ruw eiwitgehalte en energiegehalte van het ouderdierenvoer dan vrouwelijke vleeskuikens. De auteurs geven aan dat meer onderzoek noodzakelijk is, met name ook naar het effect van andere voedingsstoffen zoals mineralen, vitaminen en vetzuren (Chang et al., 2016).

Lourens en Steentjes (2008) verwijzen naar een onderzoek waarin een hoger vitaminegehalte in het voer van ouderdieren de uitval bij vleeskuikens zou verminderen. Daarnaast wordt gesuggereerd door Chang et al. (2016) dat de mate van het effect afhankelijk is van het de omstandigheden waaronder de vleeskuikens worden gehouden, wat ook wordt aangegeven door Lourens en Steentjes (2008).

Lourens en Steentjes (2008) beschrijven dat transmissie van virusziekten, schimmelziekten en bacteriële ziekten van vleeskuikenouderdieren naar vleeskuikens een groot effect kan hebben op de uitval van vleeskuikens. Naast verticale transmissie of transmissie via het ei spelen immuun suppressie en effecten daarvan op de maternale antistoffen een rol.

Bij leghennen is aangetoond dat er een relatie was tussen het ouderdierkoppel en de mate waarin verenpikken en angstigheid voorkwamen bij de nakomelingen. De effecten waren afhankelijk van de genetische achtergrond en de verklaring werd gezocht in hogere corticosteronconcentraties in de ouderdieren en de dooier die vervolgens een effect hebben op de nakomelingen (de Haas, et al., 2014). De mogelijke relatie tussen hoge corticosteronconcentraties bij ouderdieren die via de dooier een effect hebben op de nakomelingen is ook gesuggereerd voor vleeskuikenouderdieren, maar de onderbouwing voor die effecten is er nog niet (Hynd, et al., 2016). Uit enkele experimenten van deze auteurs komen wel suggesties naar voren dat factoren in het leven van vleeskuikenmoederdieren, zoals stress of voergrondstoffen, een effect hebben op het immuunsysteem en de ontwikkeling van de nakomelingen (Hynd, et al., 2016). Ook zij geven aan dat meer onderzoek naar deze mogelijke relaties noodzakelijk is.

\subsection{Conclusies}

Dit hoofdstuk is een zeer beknopte weergave van de literatuur met betrekking tot effecten van factoren of gebeurtenissen bij de ouderdieren op de gezondheid, technische prestatie en het welzijn van vleeskuikens. Uit de literatuur komt naar voren dat er zeker aanwijzingen zijn dat bepaalde factoren in het leven van vleeskuikenouderdieren, zowel in de productie- als opfokperiode, een effect hebben op de nakomelingen. Dit is met name onderzocht in relatie tot ruw eiwit- en energiegehalte van het voer van de moederdieren in de opfok en/of productiefase. Meer inzicht is echter gewenst in 
welke factoren een effect hebben op de technische resultaten en de diergezondheid in de gehele vleeskuikenketen, en hoe vervolgens aangepast management in de voorschakels kan leiden tot verbetering van diergezondheid, dierwelzijn en rendement in de vleeskuikenketen. 


\section{$4 \quad$ Discussie en conclusies}

In de vleeskuikenketen worden, routinematig, door de verschillende schakels in de productieketen gegevens geregistreerd. Dit betreft gegevens over de productie van ouderdierkoppels die worden geregistreerd door het fokbedrijf, gegevens over plaatsing van kuikens van vermeerderingskoppels die worden vastgelegd door de broederij, gegevens over de productie die worden vastgelegd door de slachterij en gegevens over het antibioticagebruik die worden geregistreerd in een nationale database. Deze gegevens worden geaggregeerd vastgelegd, dat wil zeggen, gemiddeld over de productie- of groeiperiode of een deel van deze periode. Doel van de analyse beschreven in dit rapport was het koppelen van de gegevens op de diverse niveaus in de schakels om grote bronnen van variatie in kenmerken op vleeskuikenkoppelniveau op te kunnen sporen. Een belangrijke vraag daarbij was in welke mate de voorschakels bijdragen aan de variatie in productiekenmerken op niveau van het vleeskuikenkoppel.

De analyses die worden beschreven in dit rapport zijn uitgevoerd op basis van gegevens die zijn vastgelegd in een deel van de Nederlandse reguliere vleeskuikenproductieketen, namelijk het deel van de vleeskuikenproductieketen dat bij de deelnemers aan het PPS project Gezonde Vleeskuiken hoort. Dit betekent dat het een beperkte set gegevens betreft, van vermeerderingskoppels van één fokbedrijf en één type (regulier) vleeskuiken, die leveren aan de twee broederijen, waarvan de kuikens worden afgezet aan vleeskuikenbedrijven die vervolgens weer leveren aan één vleeskuikenslachterij. Daarnaast betrof de analyse een beperkte tijdsperiode, namelijk tussen 2011 en 2014.

Bij het koppelen van de verschillende databases was het soms niet mogelijk om bij elkaar horende gegevens uit de diverse databronnen met elkaar te verbinden, door het ontbreken van KIP (unieke bedrijfsnummers) of foutief ingevoerde geboortedata. Uitgangspunt bij de analyse was dat gegevens ad random ontbraken, maar of dit daadwerkelijk zo is, kon niet getoetst worden. We hebben echter geen reden om aan te nemen dat ontbrekende gegevens van een bepaalde categorie bedrijven afkomstig zijn. Vanuit het project is een separate notitie opgeleverd die ingaat op koppeling van gegevens in databases en advies geeft over het inrichten van databases. Na koppelen en opschonen van de databases bleek het volume aan data dat overbleef voldoende voor analyse; een gemiddelde van 10 records (vleeskuikenleveringen) per vermeerderingskoppel is echter niet heel hoog. De power van de analyse zal groter worden wanneer er meer records per vermeerderingskoppel in de data aanwezig zijn. Geadviseerd wordt om de kwaliteit van de databases te verbeteren teneinde zo min mogelijk ontbrekende gegevens te krijgen, en de analyse te herhalen over een grotere tijdsperiode om te onderzoeken of de effecten die in dit rapport worden beschreven robuust zijn.

Uit de analyses van de dataset blijkt dat constante (dus ongeacht de leeftijd van de moederdieren) niveau verschillen tussen vermeerderingskoppels wat betreft resultaten in de vleeskuikenfase relatief klein zijn. Dat houdt in dat kenmerken op niveau van het vleeskuikenkoppel over het algemeen relatief weinig verschillen als gevolg van de systematische verschillen tussen vermeerderingskoppels. Het grootste effect van het vermeerderingskoppel is te zien op het percentage afkeur van vleeskuikenkoppels en de uniformiteit. Met uitzondering van een zeer klein effect op het percentage afkeur werden constante niveau verschillen tussen vermeerderingsbedrijven zelfs helemaal niet gevonden.

Hierbij moet wel rekening gehouden worden met het volgende. Het zou nog steeds zo kunnen zijn dat individuele vermeerderingskoppels een sterk afwijkend verloop in vleeskuikenkenmerken hebben met de leeftijd van de moederdieren en in die zin dus een groot leeftijdsgebonden effect geven (een verloop van laag naar hoog of andersom voor kenmerken van het vleeskuikenkoppel), maar gemiddeld gezien niet. Of hier sprake van is kan niet worden afgeleid uit de analyse die hier is uitgevoerd, hiervoor moeten meer gegevens van vleeskuikenkoppels van een zelfde vermeerderingskoppel en vermeerderingsbedrijf in de tijd worden vastgelegd en geanalyseerd. Het zou ook kunnen dat plotselinge afwijkingen (incidenten van korte duur, bijvoorbeeld aan een infectie 
die een vermeerderingskoppel doormaakt) een voorspellende waarde hebben voor de vervolgschakels. Denk aan een plotseling lager legpercentage of uitkomstpercentage als gevolg van een incident in een vermeerderingskoppel, wat mogelijk een relatief kortdurend effect heeft op kenmerken op vleeskuikenniveau. Omdat we geen gedetailleerde productiegegevens hadden, kunnen we op basis van de hier uitgevoerde analyse geen uitspraak doen over deze mogelijke effecten. In een vervolgstudie wordt dit verder onderzocht.

Verder is het nog van belang om te realiseren dat de kenmerken op het vleeskuikenbedrijf nagenoeg allemaal, behalve $1^{\mathrm{e}}$ weeks uitval, kenmerken betreffen die bij het afleveren en slachten van de kuikens worden gemeten, terwijl de invloed van voorschakels wellicht groter is op kenmerken die iets zeggen over de kwaliteit van kuikens, dus kenmerken die vroeg in het leven van het vleeskuiken van belang zijn. Eerste weeks uitval is een kenmerk dat vooral iets zegt over de voorgaande schakels (o.a., Lourens en Steentjes, 2008; Yassin et al., 2009), en dat wordt ook ondersteund door de analyse die aangeeft dat een relatief laag percentage verklaarde variantie in eerste weeks uitval door het vleeskuikenbedrijf wordt bepaald, dat een deel van de variantie wordt verklaard door vermeerderingskoppel en dat de rest van de variantie wordt verklaard door 'kuikenleverantie' en 'stal binnen kuikenleverantie'.

Wat opvalt in de analyse is dat relatief veel variatie in prestatie tussen vleeskuikenkoppels wordt verklaard door de 'rest term', waar de naam 'kuikenleverantie' voor gebruikt wordt, omdat het de specifieke variabiliteit van een batch kuikens betreft die op een bepaald moment op het vleeskuikenbedrijf wordt aangeleverd. Deze term bevat echter vele mogelijke factoren die van invloed kunnen zijn, denk hiervoor bijvoorbeeld aan de bewaarduur van eieren, broedomstandigheden, transport, maar ook kortdurende afwijkingen in kwaliteit van de eieren van een vermeerderingskoppel of kortdurende afwijkingen in de kwaliteit van opvang (management) op een vleeskuikenbedrijf. Uit de literatuur blijkt dat deze factoren of gebeurtenissen een grote invloed kunnen hebben op de kuikenkwaliteit en daarmee op de uitval in de eerste levensweek (o.a. Lourens en Steentjes, 2008; Yassin et al., 2009; Barbarosa et al., 2013).

Uit de analyses van de dataset blijkt verder dat het vleeskuikenbedrijf zelf veel van de variantie in productiekenmerken op vleeskuikenkoppelniveau kan verklaren. Dat is ook logisch, want de omstandigheden waaronder een vleeskuiken wordt gehouden hebben immers een groot effect op de uiteindelijke productieresultaten (o.a. EFSA, 2010; De Jong et al., 2012a).

Belangrijke constatering is verder dat de term 'kuikenleverantie' meestal even groot en vaak zelfs groter is dan de term 'stal binnen kuikenleverantie'. Dit betekent dat de vleeskuikens afkomstig van dezelfde batch kuikens van een vermeerderingskoppel wat betreft prestatie in de vleeskuikenfase relatief veel op elkaar lijken wanneer ze worden gehouden in verschillende stallen op het vleeskuikenbedrijf. Dit kan duiden op de invloed van de kwaliteit van de kuikens op de uiteindelijke prestaties, iets wat ook in de wetenschappelijke literatuur veelvuldig is beschreven (Decuypere et al., 2001). Nader onderzoek zal moeten uitwijzen welke factoren een belangrijke bijdrage daaraan leveren.

Wanneer gekeken werd naar de relatie tussen geaggregeerde data van vermeerderingskoppels en kenmerken op vleeskuikenniveau bleek dat er een relatie was tussen productiekenmerken (aantal eieren, uitkomstpercentage en piekproductie) van vermeerderingskoppels en het percentage uniformiteit van vleeskuikenkoppels. Hieruit bleek dat een hoge productie van een vermeerderingskoppel samenging met een slechtere uniformiteit. Verder onderzoek naar mogelijke oorzaken hiervoor is noodzakelijk. Wellicht wordt onvoldoende tegemoet gekomen aan de behoefte aan energie en voedingsstoffen bij vermeerderingskoppels die op hoog niveau produceren, waardoor de kwaliteit van de eieren minder uniform of slechter is wat mogelijk resulteert in een slechtere kwaliteit kuikens. 


\subsection{Conclusies en aanbevelingen}

Uit een retrospectieve analyse van routinematig verzamelde data van vleeskuikens- en vermeerderingskoppels binnen een deel van de reguliere vleeskuikenproductieketen bleek dat:

- Wanneer naar geaggregeerde data en constante niveau verschillen in de voorschakels wordt gekeken, en gecorrigeerd wordt voor leeftijd moederdieren, seizoen en tijdstrend, er geen systematisch effect gevonden is van vermeerderingsbedrijf op de gezondheid en prestatie van vleeskuikenkoppels;

- $\quad$ Er een gering systematisch effect gevonden is van vermeerderingskoppel op het percentage afgekeurde kuikens en de uniformiteit maar niet op de overige kenmerken (groei, antibioticagebruik, uitval $1^{\mathrm{e}}$ week en uitval totaal, en eindgewicht) van het vleeskuikenkoppel;

- $\quad$ Er een relatief grote bijdrage is van het vleeskuikenbedrijf aan de prestatie en gezondheid van vleeskuikens, naast een relatief grote bijdrage van de 'rest' (alle gebeurtenissen tussen het leggen van het ei en het plaatsen van het kuiken op het vleeskuikenbedrijf, zoals bewaarduur eieren, opvangcondities kuikens, broedomstandigheden, transport);

- Deze analyse geen uitspraak kan doen over effecten van kortdurende gebeurtenissen (zoals het doormaken van een infectie) in de voorschakels op de prestatie en gezondheid van vleeskuikens;

- Deze analyse geen uitspraak kan doen over een mogelijk verloop in effect van vermeerderingsbedrijf of vermeerderingskoppel op vleeskuikenkenmerken met toenemende leeftijd van een vermeerderingskoppel.

Het is aan te bevelen om:

- $\quad$ gezien de toch wat beperkte dataset, de analyse nogmaals te herhalen over een grotere tijdsperiode, om te bevestigen dat de gevonden resultaten robuust zijn;

- $\quad$ te onderzoeken in welke mate plotselinge gebeurtenissen in de voorschakels (zoals bijvoorbeeld het doormaken van een infectie) een invloed hebben op de prestatie van vleeskuikens. Dit vereist data die niet geaggregeerd zijn op vermeerderingsniveau alsmede aanvullende dataverzameling bij vermeerderingskoppels en in de broederijfase;

- $\quad$ te onderzoeken in welke mate de voorschakels kenmerken van vleeskuikens in de eerste levensweek beïnvloeden, aangezien naar verwachting het management op het vleeskuikenbedrijf een relatief grotere invloed op de prestatie van vleeskuikens krijgt naarmate de kuikens langer op het vleeskuikenbedrijf zijn. Dit vraagt een aanvullende registratie van data die indicatief zijn voor de prestatie (inclusief gezondheid) van vleeskuikens in de eerste levensweek. 


\section{Literatuur}

Barbosa, V. M., J. S. R. Rocha, M. A. Pompeu, N. R. S. Martins, N. C. Baiao, L. J. C. Lara, J. Batista, and R. C. Leite. 2013. The effects of relative humidity and turning in incubators machines on the incubation yield and chick performance. Worlds Poult. Sci. J. 69:89-97. doi 10.1017/s0043933913000081

Berghof, T. V. L., H. K. Parmentier, and A. Lammers. 2013. Transgenerational epigenetic effects on innate immunity in broilers: An underestimated field to be explored? Poultry Science 92:2904-2913. doi 10.3382/ps.2013-03177

A. Chang, J. Halley, A and M. Silva. 2016. Can feeding the broiler breeder improve chick qualityand offspring performance? Anim. Prod. Sci. 56: 1254-1262.

Decuypere, E., K. Tona, V. Bruggeman, and E. Bamelis. 2001. The day-old chick: a crucial hinge between breeders and broilers. Worlds Poult. Sci. J. 57:127-138.

De Haas, E. N., J. E. Bolhuis, B. Kemp, T. G. G. Groothuis, and T. B. Rodenburg. 2014. Parents and Early Life Environment Affect Behavioral Development of Laying Hen Chickens. Plos One 9. doi 10.1371/journal.pone.0090577

De Jong, I. C., A. Lourens, and J. van Harn. 2015. Effect of hatch location and diet density on footpad dermatitis and growth performance in broiler chickens. J. Appl. Poult. Res. 24:105-114. doi 10.3382/japr/pfv014

De Jong, I. C., C. Berg, A. Butterworth, and I. Estevez. 2012a. Scientific report updating the EFSA opinions on the welfare of broilers and broiler breeders. EFSA Journal 9. doi 10.2903/sp.efsa.2012.EN-295View

De Jong, I. C., J. van Harn, H. Gunnink, V. A. Hindle, and A. Lourens. 2012b. Footpad dermatitis in Dutch broiler flocks: Prevalence and factors of influence. Poultry Science 91:1569-1574.

EFSA. 2010. Scientific opinion on the influence of genetic parameters on the welfare and the resistance to stress of commercial broilers. EFSA Journal 8:1666. doi doi.10.2903/j.efsa.2010.1666

Enting, H., W. J. A. Boersma, J. B. W. J. Cornelissen, S. C. L. van Winden, M. W. A. Verstegen, and P. J. van der Aar. 2007. The effect of low-density broiler breeder diets on performance and immune status of their offspring. Poultry Science 86:282-290.

Hynd, P. I., S. Weaver, N. M. Edwards, N. D. Heberle, and M. Bowling. 2016. Developmental programming: a new frontier for the poultry industry? Animal Production Science 56:1233-1238. doi 10.1071/an15373

Koppenol, A., E. Delezie, H. K. Parmentier, J. Buyse, and N. Everaert. 2015. Limited evidence for transgenerational effects of maternal dietary supplementation with omega-3 fatty acids on immunity in broiler chickens. Veterinary Journal 203:244-249. doi 10.1016/j.tvjl.2014.12.006

Lourens, A., Steentjes, A., 2008. Zoötechnische en veterinaire factoren op vermeerderingsniveau: effecten op uitval bij vleeskuikens. Animal Sciences Group Rapport 194.

Rebel, J. M. J., S. Van Hemert, A. J. W. Hoekman, F. R. M. Balk, N. Stockhofe-Zurwieden, D. Bakker, and M. A. Smits. 2006. Maternal diet influences gene expression in intestine of offspring in chicken (Gallus gallus). Comparative Biochemistry and Physiology a-Molecular \& Integrative Physiology 145:502-508. doi $10.1016 /$ j.cbpa.2006.08.035

Tona, K., O. Onagbesan, B. De Ketelaere, V. Bruggeman, and E. Decuypere. 2007. A model for predicting hatchability as a function of flock age, reference hatchability, storage time and season. Arch. Geflugelkd. 71:30-34.

van der Waaij, E. H., H. van den Brand, J. A. M. van Arendonk, and B. Kemp. 2011. Effect of match or mismatch of maternal-offspring nutritional environment on the development of offspring in broiler chickens. Animal 5:741-748. doi 10.1017/s1751731110002387

van Emous, R. A., R. P. Kwakkel, M. M. van Krimpen, and W. H. Hendriks. 2015a. Effects of dietary protein levels during rearing and dietary energy levels during lay on body composition and reproduction in broiler breeder females. Poultry Science 94:1030-1042. doi 10.3382/ps/pev079

van Emous, R. A., R. P. Kwakkel, M. M. van Krimpen, H. van den Brand, and W. H. Hendriks. 2015b. Effects of growth patterns and dietary protein levels during rearing of broiler breeders on fertility, hatchability, embryonic mortality, and offspring performance. Poultry Science 94:681-691. doi 10.3382/ps/pev024

Yassin, H., A. G. J. Velthuis, M. Boerjan, and J. van Riel. 2009. Field study on broilers' first-week mortality. Poultry Science 88:798-804. doi 10.3382/ps.2008-00292

Yassin, H., A. G. J. Velthuis, M. Boerjan, J. van Riel, and R. B. M. Huirne. 2008. Field Study on Broiler Eggs Hatchability. Poultry Science 87:2408-2417. doi 10.3382/ps.2007-00515 


\section{Bijlage 1 Verklaring termen}

\section{Term Definitie}

Kuikenleverantie Alle kuikens afkomstig van dezelfde moederdierkoppel die op dezelfde dag zijn uitgekomen en worden afgeleverd aan vleeskuikenbedrijven

Uniformiteit Het percentage kuikens $<65 \%$ van het gemiddelde grillergewicht van een koppel, d.w.z. een hoger percentage is negatief want een minder uniform koppel

Groei-index Een nar afleverdatum gecorrigeerde mat voor de groei van een koppel vleeskuikens

Tijdstrend Vast effect van de tijd (looptijd data registratie, d.w.z. tussen 2011 en 2014) op een parameter

Seizoenstrend Vast effect van het seizoen binnen een jaar op een parameter

Leeftijd Vast effect van de leeftijd van de moederdieren op een parameter

moederdieren

trend 


\section{Bijlage 2 Effecten van trend, seizoen en leeftijd moederdieren}

Tabel Schattingen voor effecten van trend, seizoen en leeftijd moederdieren. ns=niet significant; overige effecten zijn significant met $P<0.05$.

\begin{tabular}{|c|c|c|c|c|c|c|}
\hline & $\begin{array}{l}\beta_{1.1} \\
\text { tijdstrend } \\
\text { (lineair) }\end{array}$ & $\begin{array}{l}\beta_{1} \text {. } \\
\text { tijdstrend } \\
\text { (kwadr.) }\end{array}$ & $\begin{array}{l}\beta_{2} \\
\text { seizoen } \\
\text { (sinus) }\end{array}$ & $\begin{array}{l}\beta_{3} \\
\text { seizoen } \\
\text { (cosinus) }\end{array}$ & $\begin{array}{l}\beta_{4} \\
\text { lft_moeders } \\
\text { (lineair) }\end{array}$ & $\begin{array}{l}\beta_{5} \\
\text { lft_moeders } \\
\text { (loglineair) }\end{array}$ \\
\hline Groei & 0.0012 & - & $-0.059^{N S}$ & $0.11^{\mathrm{NS}}$ & $-0.059^{N S}$ & 2.59 \\
\hline Groei-index & 0.0013 & - & $0.33^{\mathrm{NS}}$ & $-0.04^{\mathrm{NS}}$ & $-0.14^{\mathrm{NS}}$ & 6.67 \\
\hline Eindgewicht & 0.0001 & - & $-0.015^{\mathrm{NS}}$ & $0.016^{\mathrm{NS}}$ & $-0.002^{\text {NS }}$ & 0.089 \\
\hline Perc. afkeuringen & $0.000004^{\mathrm{NS}}$ & - & 0.002 & 0.004 & $0.00^{\mathrm{NS}}$ & $0.002^{\mathrm{NS}}$ \\
\hline Perc. uniformiteit & -0.00002 & $2.7 * 10^{-8}$ & $-0.000^{N S}$ & 0.002 & $0.00008^{\mathrm{NS}}$ & $0.001^{\mathrm{NS}}$ \\
\hline Perc. uitval week 1 & $0.00006^{\mathrm{NS}}$ & - & $0.007^{\mathrm{NS}}$ & 0.08 & $0.005^{\mathrm{NS}}$ & $-0.12^{\text {NS }}$ \\
\hline Perc. uitval totaal & 0.0002 & - & 0.039 & 0.061 & $0.004^{\mathrm{NS}}$ & $-0.049^{N S}$ \\
\hline Dagdoseringen $A B$ & -0.0005 & - & $0.051^{\mathrm{NS}}$ & $0.016^{\mathrm{NS}}$ & $0.02^{\mathrm{NS}}$ & $0.20^{\mathrm{NS}}$ \\
\hline
\end{tabular}




\section{Bijlage 3 Schattingen voor variantiecomponenten}

Tabel Schattingen van variantiecomponenten voor vermeerderingsbedrijf (VM), vleeskuikenbedrijf $(V K)$ en kuikenleverantie ( $K L)$ en combinaties (VMxVK en stal binnen $K L$ ) voor de diverse vleeskuikenkenmerken.

\begin{tabular}{|c|c|c|c|c|c|c|c|}
\hline & $\begin{array}{l}\underline{\varepsilon}_{i} \\
\text { bedrijifs- } \\
\text { effect }\end{array}$ & $\begin{array}{l}\underline{\varepsilon}_{i j} \\
\text { koppel- } \\
\text { effect }\end{array}$ & $\begin{array}{l}\underline{\varepsilon}_{k} \\
\text { bedrijis- } \\
\text { effect }\end{array}$ & $\begin{array}{l}\underline{\varepsilon}_{k m} \\
\text { stal- } \\
\text { effect }\end{array}$ & $\begin{array}{l}\underline{\varepsilon}_{i k} \\
\text { specifieke } \\
\text { combinatie }\end{array}$ & $\begin{array}{l}\underline{\varepsilon}_{i j k l} \\
\text { kuiken- } \\
\text { leverantie }\end{array}$ & $\begin{array}{l}\underline{\varepsilon}_{i j k l m} \\
\text { Stal } \\
\text { binnen }\end{array}$ \\
\hline & VM & VM & VK & VK & VM $\times$ VK & KL & KL \\
\hline Groei & 0.00 & 0.45 & 5.42 & 0.16 & 0.38 & 4.75 & 2.10 \\
\hline Groei-index & 0.00 & 3.55 & 68.58 & 2.31 & 2.94 & 30.15 & 11.88 \\
\hline Eindgewicht & 0.00 & 0.0019 & 0.014 & 0 & 0.00 & 0.018 & 0.008 \\
\hline Perc. afkeuringen & 0.000005 & 0.00004 & 0.00006 & 0.000004 & 0.00 & 0.00018 & 0.00022 \\
\hline Perc. uniformiteit & 0.00 & 0.00001 & 0.00002 & 0.000004 & 0.00 & 0.000036 & 0.000038 \\
\hline Perc. uitval week 1 & 0.00 & 0.008 & 0.023 & 0.0006 & 0.00 & 0.054 & 0.052 \\
\hline Perc. uitval totaal & 0.00 & 0.0087 & 0.048 & 0.001 & 0.00 & 0.059 & 0.040 \\
\hline Dagdoseringen $A B$ & 0.00 & 0.089 & 0.78 & 0.00 & 0.00 & 2.26 & 1.62 \\
\hline
\end{tabular}




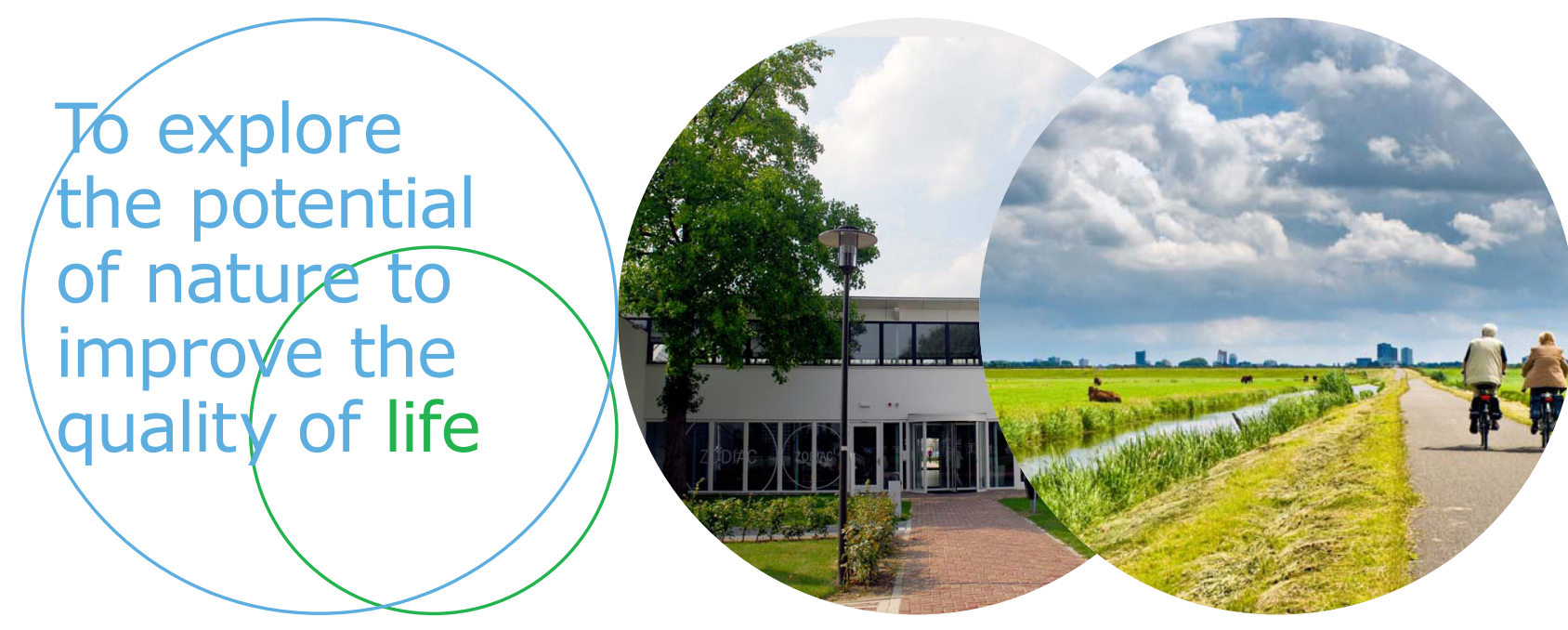

Wageningen Livestock Research Postbus 338

$6700 \mathrm{AH}$ Wageningen

T 0317483953

E info.livestockresearch@wur.n www.wur.nl/livestock-research
Wageningen Livestock Research ontwikkelt kennis voor een zorgvuldige en renderende veehouderij, vertaalt deze naar praktijkgerichte oplossingen en innovaties, en zorgt voor doorstroming van deze kennis. Onze wetenschappelijke kennis op het gebied van veehouderijsystemen en van voeding, genetica, welzijn en milieu-impact van landbouwhuisdieren integreren we, samen met onze klanten, tot veehouderijconcepten voor de 21 e eeuw.

De missie van Wageningen University \& Research is 'To explore the potential of nature to improve the quality of life'. Binnen Wageningen UR bundelen 9 gespecialiseerde onderzoeksinstituten van stichting DLO en Wageningen University hun krachten om bij te dragen aan de oplossing van belangrijke vragen in het domein van gezonde voeding en leefomgeving. Met ongeveer 30 vestigingen, 6.000 medewerkers en 10.000 studenten behoort Wageningen UR wereldwijd tot de aansprekende kennisinstellingen binnen haar domein. De integrale benadering van de vraagstukken en de samenwerking tussen verschillende disciplines vormen het hart van de unieke Wageningen aanpak. 